\title{
№ 38
}
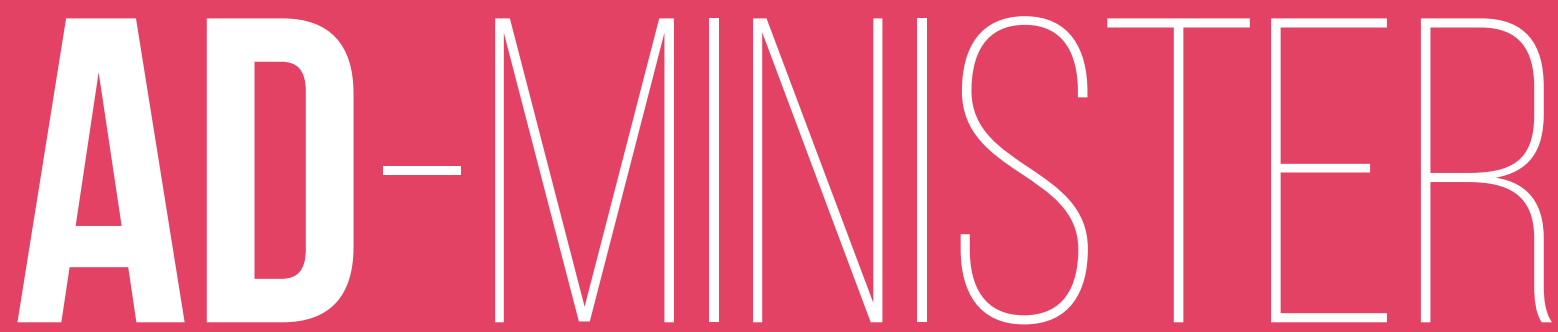

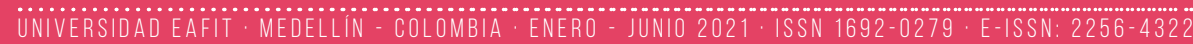

KHALED SALMEN ALJAAIDI

SHAMHARIR BIN ABIDIN

WADDAH KAMAL HASSAN

JEL: N45 AND M42

DOI: https://doi.org/10.17230/ Ad-minister.38.5

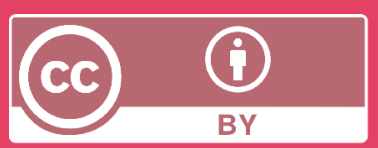




\section{AUDIT FEES AND AUDIT QUALITY: EVIDENCE FROM GULF COOPERATION COUNCIL REGION HONORARIOS DE AUDITORÍA Y CALLIDAD DE LA AUDTTORÍA: EVIDENCIA DE LA REGIÓN DEL CONSEJO DE
COOPERACIÓN DEL GOLFO}

KHALED SALMEN ALJAAIDI ${ }^{1}$

SHAMHARIR BIN ABIDIN²

WADDAH KAMAL HASSAN ${ }^{3}$

JEL: N45 AND M42

RECEIVED: $20-05-2020$

MODIFIED: $20-04-2021$

ACCEPTED: $20-05-2021$

DOI: https://doi.org/10.17230/ Ad-minister.38.5

\section{ABSTRACT}

This study examines the association of audit fees with audit quality among a total of 104 and 108 nonfinancial companies listed on The Gulf Cooperation Council stock markets for the periods preceding and subsequent to the event, respectively, over the period 2005-2010. Using OLS regression, the results show that there is a significantly positive association between audit fees and audit quality for the periods preceding and subsequent to the new auditor selection. Furthermore, the results of this study contribute to the existing theory and empirical evidence indicating how audit fees are associated with audit quality in the periods preceding and subsequent to the new auditor selection. This study offers policy-makers additional evidence to utilize for setting up and/or enacting regulations in The Gulf Cooperation Council region, regarding issues related to audit fees.

\section{KEYWORDS}

Audit fees, audit quality, Gulf Co-operation Council region.

\section{RESUMEN}

Este estudio examina la asociación de los honorarios de auditoría con la calidad de la auditoría entre un total de 104 y 108 empresas no financieras que cotizan en los mercados de valores del Consejo de Cooperación del Golfo para los períodos anteriores y posteriores al evento, respectivamente, durante el período 2005-2010. Utilizando la regresión OLS, los resultados muestran que existe una asociación significativamente positiva entre los honorarios de auditoría y la calidad de la auditoría para los períodos anteriores y posteriores a la selección del nuevo auditor. Además, los resultados de este estudio contribuyen a la teoría existente y la evidencia empírica de cómo los honorarios de auditoría están asociados con la calidad de la auditoría en los períodos anteriores y posteriores a la selección del nuevo auditor. Este estudio ofrece a los responsables de la formulación de políticas evidencia adicional que se utilizará para establecer y / o promulgar regulaciones en la región del Consejo de Cooperación del Golfo con respecto a cuestiones relacionadas con las tarifas de auditoría.

\section{PALABRAS CLAVE}

Honorarios de auditoría, calidad de la auditoría, región del Consejo de Cooperación del Golfo.
1 Accounting Department, College of Business Administration, Prince Sattam bin Abdulaziz University, Email: k.aljaaidi@psau.edu.sa

2 School of Accountancy, UUM College of Business, Universiti Utara Malaysia. Email: sham1202@uum. edu.my

3 Accounting Department, Faculty of Administrative Sciences, University of Aden, Yemen, and Department of Accounting, College of Business Administration. Northern Border University, Saudi Arabia. Email: waddahkam@Yahoo.com ORCID = 0000-0001-9777-7497 


\section{BACKGROUND OF THE STUDY}

Although recent institutional changes in The Gulf Cooperation Council (GCC) region, namely, in Saudi Arabia, Oman, Qatar, Bahrain, and The United Arab Emirates, would place an increasing demand for audit services, some concerns associated with the audit function still exist. Few audit failures have occurred, and qualified audit reports have been received during the entire history of the GCC. In particular, the Big 4 audit firms have been involved in two cases (Al-Shammri et al., 2008; Asiri, 2009). Al-Shammari et al. (2008) argue that the low number of reported audit failures in the GCC does not reflect a good audit function. Rather, Al-Gahtani (2005) argues that the accounting and auditing professions are still under development in terms of presence and enforcement. The audit function, at this point, is concerned only with issues related to recording financial transactions, keeping source documents, preparing financial statements, and auditing financial statements by licensed auditors.

As world economic powers, the six oil-based members of the GCC-Saudi Arabia, Bahrain, Kuwait, Qatar, Oman, and The United Arab Emirates, share a large number of economic, cultural, and political similarities, which far outweigh any differences (Al-Hussaini, Al-Shammari, \& Al-Sultan, 2008; Aljifri \& Moustafa, 2007; Al-Muharrami, Matthews, \& Khabari, 2006; Chahine \& Tohme, 2009). The audit markets of the GCC have suffered from a paucity of research in past decades. This situation exists particularly because of the restrictions imposed on foreign stock ownership, the lack of common accounting and auditing regulations, and the uncertainty of economic and political conditions. Recently, however, GCC countries have adopted and developed large-scale economic and market policies and strategies that lend themselves to market-oriented economies. These include high oil prices, low interest rates, 100\% foreign ownership, strong international oil demand, a stable geo-political environment, acceleration of reform measures, an increase in privatization programs, lifting of investment restrictions, a strong GCC corporate sector, low aggressive tax regimes, improvement of accounting and auditing regulations, and the establishment and enacting of corporate governance codes (Al-Shammari et al., 2008; Bley \& Chen, 2006; Hussain, Islam, Gunasekaran \& Maskooki, 2002; Omran, Bolbol \& Fatheldin, 2008).

In the GCC, the disclosure of issues related to auditor change or rotation of audit firms is explicitly addressed in a weak manner within the codes of corporate governances. In this regard, only Omani and Qatari codes of corporate governance state that a mandatory rotation policy should be applied every four and three years, respectively. The Bahraini code of corporate governance indicates that the company shall disclose items related to reasons for any changing and reappointing of auditors (Al-Shammari et al., 2008; Chahine \& Tohme, 2009; Harabi, 2007; Hawkamah and IFC, 2008; Omran et al., 2008). For example, according to Hawkamah and the IFC survey of 2008, approximately $47 \%$ of listed companies in MENA countries (i.e., GCC) indicated that they made an auditor change. Furthermore, a large majority 
of banks and listed companies in the MENA region (i.e., GCC), namely 68.8\% of listed companies, employ international audit firms (Binder, 2009). Under these circumstances, these concerns have negatively influenced the structure of the audit service market in the GCC, and agency problems are more likely to arise between majority and minority shareholders. Therefore, the GCC region is a unique position in terms of the context of auditor change. There is an ambiguity regarding the possible effects of auditor change on auditor independence in the GCC context.

However, to date, no single theory explains why companies switch from one auditor to another (DeAngelo, 1982; Grayson, 1999; Knapp \& Elikai, 1988; Schwartz \& Menon, 1985). Additionally, no broad theory exists to explain how firms choose a new auditor, or weigh the cost tradeoffs in switching auditors (Blouin, Grein, \& Rountree, 2005). Moreover, Clarkson and Simunic (1994) report that up until now, a comprehensive set of endogenous and exogenous variables that are related to audit quality are not determined by the existing theories. In addition, it is difficult to categorize the potential determinants influencing auditor choice based on the underlying theories, because of the incompleteness of the underlying theories related to auditor choice; the overlapping of the theories with each other; (Wallace, 1984) and the ignorance of behavioral issues related to auditor choice (Beattie \& Fearnley, 1998). Consistent with this, Meyer (2006) indicates that theories based on Western countries may be unsuitable for, and irrelevant to, other countries.

Previous studies on auditor choice have been conducted primarily in countries with Anglo-Saxon legislation, such as the U.S and U.K, and they are heavily based on agency theory. Furthermore, they have resulted in contradictory and inconclusive results. Thus, the findings of the previous studies might not be applicable in the context of the GCC, which is a dissimilar setting in terms of the audit market, institutional framework, level of regulatory enforcement, and culture. In this regard, DeFond and Francis (2005) call for research on auditor choice outside the U.S. It is emphasized that there should a comprehensive corporate governance perspective that takes into consideration the various national institutions where corporate governance practices are set in (Cortes, Echeverry, Ramirez and Yaque, 2017; Riano, 2009; Aguilera, 2005; Pugliese et al., 2009). In light of these deficiencies, audit quality issues seem to require further empirical investigation. Haniffa and Hudaib (2007) report that a paucity of research exists concerning audit function in the GCC. This appears to still be a vague situation in the GCC, and to the best of the researchers' awareness there is a lack of empirical research showing the association of audit fees and auditor choice. Thus, this study examines factors leading to auditor change in the GCC countries.

Among earlier and recent research on auditing, no consensus has been reached regarding the existence of a single proxy for audit quality; namely, that available proxies have more than one measurement is more important. DeFond (1992) indicates that studies on auditor choice, and methodologically, lack a comprehensive proxy for audit quality. DeAngelo (1981) has stated that audit quality is an unobservable 
task and, therefore, is difficult to be evaluated objectively. In this regard, economists indicate that market participants may come out with proxies measuring quality services when they are involved in quality-differentiated marketplaces (Barzel, 1982). Empirically, several audit-quality surrogates have been used in early and recent extant research on auditor choice. Unfortunately, mixed and inconclusive results have been reported by these studies (Al-Ajimi, 2009). Haskins and Williams (1990) have suggested that the conflicting findings among previous studies on auditor choice could be attributed to the extensive of restricted operationalization of audit quality as a binary indicator. Therefore, in the social science research field, there has been strong support for the use of multiple indicators of theoretical constructs. Nunnaly and Bernstein (1994, p.86) argue that "because constructs concern domains of observables, a better measure of any construct is obtained by combining the results from a number of measures than by taking any one of them individually. Similarly, combining several observables provides greater construct validity and scientific generalizability, in the domain as a whole, relative to a single measure."

In support of this, Agrawal and Knoeber (1996) have argued that misleading results occur when showing the effect of one single indicator and not considering multiple indicators of theoretical constructs. In the same vein, O'Sullivan, Percy and Stewart (2008) have stated that investigating the overall mechanisms gives a stronger effect of measurement than just examining them individually. One of the more rigorous studies using a complex measurement of audit quality is that conducted by DeFond (1992) in the U.S. This study uses a combination of four audit quality surrogates that have a recurring presence in the literature: brand-name auditor, auditor size, industry specialist, and auditor independence. DeFond (1992) reports that a combination of measurements can be used to capture the same underlying construct-the auditor's ability to alleviate agency conflicts. Consequently, the combination of these four measurements may provide more information than if they are used individually. He also indicates that testing hypotheses using each of the auditor characteristics would be considered a "noisy" measure of audit quality. Therefore, combining the four measurements may increase the power of the tests and would, in turn, reduce noise in the independent variable.

This study extends previous studies on auditor choice and adopts the combined measure of audit quality in DeFond's (1992) sole study, a U.S.-based study, which comprises four surrogates: brand name auditor, auditor independence, auditor size, and auditor expertise. This study compares different time periods than that of DeFond's (1992); as the U.S. and the GCC have different institutional and business environments, audit markets, and culture. This study is expected to report different results than those of DeFond (1992). In addition, this current study addresses audit fees, which have not been examined empirically within the framework of auditor selection based on DeFond's (1992) study (Model 2). Based on the suggestions of agency theory, different levels of audit fees may lead to a variation in the demand for audit quality (Fama \& Jensen, 1983; Jensen \& Meckling, 1976; Wallace, 1980, 1987). 
Woo and Koh (2001) document that audit fee has been suggested as a relevant determinant in explaining variation in the demand for audit quality. AL-Qadasi et al. (2019) argue that different conflicts of interest in the Malaysian context affect auditor choice and audit fees will enrich the extant auditing literature.

A substantial amount of previous studies on auditor choice excluded the variable of audit fee from their models due to the fact that audit fee data are difficult to obtain because of its proprietary nature. Palmrose, (1986) and Simunic, (1980) report that there is an association between firm size and audit fees. In specific, some empirical studies collected audit fee information directly from companies (Palmrose, 1982; Simunic, 1980; Wallace, 1984). However, they documented a low response rate. In the GCC, companies are not required by law to mandatory disclose their audit fees. DeFond (1992) reports that, because of the difficulty in obtaining audit fee data, it is appropriate to estimate the size of the company relative to the audit firm's total client base, using data on company revenues. Following the work of DeFond (1992), this study adopts a similar measurement in estimating audit fees. The aim of this study is to examine the association between audit fees and audit quality for a total of 104 and 108 non-financial companies listed on the GCC stock markets for the periods preceding and subsequent the event, respectively, over the period 2005-2010.

The remainder of this paper is structured accordingly. Section two reviews the literature and develops the hypothesis. Section three highlights the research method. Section four reports the results and discussions. The final section illustrates the conclusion.

\section{LITERATURE REVIEW AND DEVELOPMENT OF HYPOTHESIS}

According to the agency theory, audit fees with various levels can lead to change in the demand for audit quality (Fama \& Jensen, 1983; Jensen \& Meckling, 1976; Wallace, 1980, 1987). Audit quality has a direct relationship to the independence of the auditor given that without independence, the opinion of the audit is meaningless. The various levels of audit fees cause the effects of economic dependence of the auditor on the audit client (Bryan-Low, 2003; Gunny et al., 2007; Weil \& Tannenbaum, 2001).

Empirical studies have shown that the Big-8 audit firms may likely have larger fees due to the quality of their work that is high, the influence of their reputation, the related costs involved, and the position of their oligopolistic market, especially in the case of the larger audited firm. It is expected that the Big-8 fees are lower, due to economies of scale of the auditor (Pong \& Wittengton, 1994). Studies such as Beattie and Fearnley (1995); Bedard et al. (2000); DeAngelo (1981a); Ettredge and Greenberg (1990); Hogan (1997); Turpen (1990); and Simon \& Francis (1988) have indicated that a firm's cost saving for the client, which was brought about by a decrease in audit fee, is a significant justification for the changing of auditors by the firms for a less costly one.

According to the report of a study in US by Simon and Francis (1988), client firms made a lower payment for fees relative to the higher ones that they would have paid if the clients had had the features of necessary fees in the earlier three years of their 
engagement in the audit. On average, the fee discount of $24 \%$ was found at the earlier year of engagement in the audit. The discount disappears after having remined for an extra two years at this low level. In particular, they show that a reduction in fee which brings about switches of auditors, could show variation in the quality of the auditor or efficiency in the level of technology, as compared to the form of fee reduction that constitute a threat to the independence of auditor. The test was done again, in order to make corrections for the impacts of unexpected results, by making use of observations from the same level of auditor changes only.

With respect to a given client, the assumption was made that there is an absence of any significant differences in efficiency between auditors belonging to the same class and to those with comparable reputations among the auditors of a given class. The same outcome was arrived at as that determined from a subsample with the use of statistical tests, and those with the same levels of auditor variation. The conclusion determined was that reduction of fee could worsen the problem associated with independence caused by the presence of quasi-rents as analyzed by DeAngelo (1981a). In their study, Beattie and Fearnley (1995) find that in the UK listed companies, $66 \%$ of them that deemed it necessary to change their auditor, gave the current levels of audit fee ranking as a motive for deeming it necessary to have such a change. Pong and Whittington (1994) have also provided analysis of the effect encountered in the first year of changing the auditor, and pointed out that the new auditors appointed have the tendency of charging a lower fee as compared to incumbent auditors. Furthermore, Woo and Koh (2001) show that if companies have the feeling that there is no significance difference that exits in the quality of the audit provided with the lower audit fee charged, then the companies will appoint another auditor. Hudiab and Cooke (2005) observe that with a higher level of fee, there are fewer tendencies for a qualified audit to give an opinion because a client will not want to allow an audit qualification if the audit fees paid are higher than average.

In spite of the fact that firms obtain the services of auditors whose charges are the cheapest justify the fact that many reasons abound for the discouragement of firms from the continuous variation of auditors, just to conserve audit fees (Kallunki, Sahlstrom \& Zerni, 2007; Lindahl, 1996). The costs of switching as described by Klemperer (1995) refers to the special costs that the customers incur as suppliers are changed. The costs of switching occur due to the fact that customers who had earlier bought services from one supplier encounter extra costs in a case where they choose to switch to another supplier for the same services. Due to the fact that the costs of switching offer firms a kind of monopolistic power, the firms encounter an opportunity cost to either invest in market share by reducing the price charge to have new customers, or the firms realize profits by increasing the prices charge relative to the existence of the customer relationships. With the presence of switching costs, several studies have confirmed the preference of business relations with a long period in industries that produce complex and tailored goods or services (Campbell, 1985; Ford et al., 1986; Stewart, 1998). 
The report by Francis (1984) and Simunic (1980) confirms inconsistent results with respect to audit services pricing while Simunic (1980) reports that in the US market, audit prices bear no significant difference between the Big-8 and the nonBig-8 audit firms, in a small sample of companies characterized as having sales of lesser than \$ 125 million, and a large sample of companies characterized as having sales greater or equal to $\$ 125$ million. This finding is consistent with the structure of a competitive market without product differentiation to the Big-8 audit firms. As a contradiction, it was reported by Francis (1984) that in the Australian market, audit prices associated with the Big- 8 was considerably greater than those associated with the non-Big-8 in the small and large sample of companies. The results provide consistency with a structure of a competitive market with product differentiation to the Big-8 audit firms. The distinction in the size of auditee in the foregoing two studies might provide for an explanation for the resultant contradiction. In Simunic (1980), the average size of asset for small and large auditees amounted to \$177 and $\$ 892$ million (US dollars), respectively, as distinct from that in Francis (1984) with \$8 and $\$ 90$ million (Australian dollars). The distinctions in the size of auditee indicate that Simunic and Francis appear to identify two samples stemming from the larger and smaller end of the size continuum, respectively. On this basis, Francis would have no ability to generalize with respect to "larger" auditees regarding the Big-8 product differentiation.

Simunic's model has been tested by other studies by using various time periods and industries in analyzing data. Others have examined the particular factors determining the audit fee by the firms in various countries as well as in different institutional environments (Craswell et al., 1995; Francis et al., 2003; Taylor \& Simon, 1999). In recent studies, Che Ahmad et al. (2006) have empirically reported that there is a positive association between auditor choice among brand name and audit fees. Woo and Koh (2001) find that higher audit fees are associated with auditor changes. Cassell et al. (2012) document a significantly negative association between abnormal audit fees and the auditor change from the Big 4 to the non-Big 4 audit firms. Fargher et al. (2001) report an insignificant association between audit fees and in the selection of the Big-6 audit firms. Salehi et al. (2019) show no significant relationship between audit quality and audit fees stickiness. Salehi et al. (2017) find no significant relationship between audit fees pressure and audit quality. In addition, an insignificant association has been reported by Jung et al. (2016) between audit quality and abnormally high audit fees. In this same regard, Hudaib and Cooke (2005) find an insignificant relationship between audit fees and the propensity to switch for distressed qualified auditees and management director change. In their pre-SAS600 model, they find that audit fees are associated with auditor change and, in post-SAS600, they could not find no such association. Nazri et al. (2012b) find that audit fees are positively related to audit quality. With this in mind, studies linking audit fees with auditor choice produce contradictory results. 
Regarding background associated with the above discussion, the present study proposes direct associations between audit fees and the audit quality. The testable hypotheses are identified in direct forms, respectively:

H1: Ceteris paribus, there is a positive association between audit fees and audit quality.

\section{RESEARCH METHOD}

\section{Sample and Data Collection}

The population of interest is comprised of all non-financial companies listed on the Stock Exchanges of the five members of the Gulf Cooperation Council (GCC) with auditor switches occurring during the period from 2006 to 2009. This selection is the most recent test period for which data were available. Further, the boom of the GCC clearly emerged in early 2005 (Chahine \& Tohme, 2009). A span of a four-year period was employed because it was assumed to be superior to a shorter period, which might be more susceptible to unusual events. A period longer than four years, however, would extend the company comparisons to a time period too long after the auditor change event to be of interest. Another reason for using a fouryear period is that this study is restricted by the data availability. The information has been gathered as the result of two points in time: (1) the first fiscal year-end " $t-{ }_{1}$ " (before an auditor change): to correspond approximately to the year before the auditor change, and (2) the third year-end " $t$ " (after the auditor change): to correspond approximately to the year after the auditor change. Further, this study targets companies that have not changed their auditors in the auditor change as they did not change their auditors between 2006 and 2009.

All data that are denominated in several currencies of the five members of the GCC are translated into US dollar equivalents for the purpose of the study. For the purpose of minimizing the noise and voiding the including of proxies surrogating for non-agency cost variables, several non-agency cost motivated variables that lead to the cases of auditor changes are excluded as follows. First, companies that have experienced a bankruptcy (DeFond, 1992; Lee, Mande \& Ortman, 2004; Menon \& Williams, 2008; Carcello \& Neal, 2003). Second, companies that have selected a new auditor twice or more during the period considered in this study are eliminated from the sample (DeFond, 1992; Khalil et al., 2010; Chan et al., 2007). Third, companies that own subsidiaries of other companies of $20 \%$ or greater are also excluded from the sample in the current study (DeFond, 1992; Johnson \& Lys, 1990). Fourth, companies that change their auditors because of merging at any time during the period considered in this study are excluded (Johnson \& Lys, 1990; Lennox, 2000; Khalil et al., 2010). Fifth, companies that have received adverse or disclaimer opinions at any time during the period considered in this study are eliminated (DeFond, 1992). Sixth, companies that have changed their auditors because of a mandatory rotation policy (DeBerg et al., 1991). Seventh, companies that are engaged in banking, insurance or diversified financial services are excluded (e.g., Hudiab \& Cooke, 2005; Chan et al., 
2007; Jackson, Moldrich \& Roebuck, 2008; Desender et al., 2009; Carcello \& Neal, 2003). And, finally, companies whose auditors resign are also eliminated (Carcello \& Neal, 2003; Robinson \& Jackson, 2009).

Applying the above criteria, excluding non-auditor change companies, and also eliminating companies with incomplete data, the sample size was reduced to 109 auditor-change companies that have experienced a change in their audit quality. After the screening process for the two-year periods; before $\left(t_{-}\right)$and after $\left(t_{1}\right)$ the auditor selection, five cases of multivariate outliers have been detected for the pre-auditor-selection model, and one case has been reported for the post-auditorselection model. Thus, a final sample of 104 and 108 companies were identified to be eligible for inclusion in the analysis of the pre-auditor-selection model $\left(\mathrm{t}^{-}\right)$and postauditor-selection model $\left(t_{1}\right)$, respectively. A breakdown of the sample by year using the brand-name classification is shown in Table 3.1.

Table 3.1. Summary of Auditor Change Types (Big 4/Second Tier/Local - Classifications*)

\begin{tabular}{|c|c|c|c|c|c|c|}
\hline & \multicolumn{2}{|c|}{ Upgrade Change } & \multirow{2}{*}{$\begin{array}{l}\text { Par } \\
\text { Change } \\
0\end{array}$} & \multicolumn{2}{|c|}{ Downgrade Change } & \multirow[b]{2}{*}{ Total } \\
\hline & +2 & +1 & & -1 & -2 & \\
\hline \multirow{2}{*}{2006} & 0 & 0 & 3 & 1 & 0 & 4 \\
\hline & $(0 \%)$ & $(0 \%)$ & $(4 \%)$ & $(6 \%)$ & $(0 \%)$ & $(4 \%)$ \\
\hline \multirow{2}{*}{2007} & 1 & 5 & 10 & 8 & 0 & 24 \\
\hline & $(100 \%)$ & $(24 \%)$ & $(15 \%)$ & $(44 \%)$ & $(0 \%)$ & $(22 \%)$ \\
\hline \multirow{2}{*}{2008} & 0 & 10 & 30 & 6 & 1 & 47 \\
\hline & $(0 \%)$ & $(48 \%)$ & $(44 \%)$ & $(33 \%)$ & $(100 \%)$ & $(43 \%)$ \\
\hline \multirow{2}{*}{2009} & 0 & 6 & 25 & 3 & 0 & 34 \\
\hline & $(0 \%)$ & $(28 \%)$ & $(37 \%)$ & $(17 \%)$ & $(0 \%)$ & $(31 \%)$ \\
\hline \multirow[b]{2}{*}{ Totals } & 1 & 21 & 68 & 18 & 1 & 109 \\
\hline & $(1 \%)$ & $(19 \%)$ & $(62 \%)$ & $(17 \%)$ & $(1 \%)$ & $(100 \%)$ \\
\hline
\end{tabular}

*Where

$+2=$ from local firm to Big 4

$+1=$ from local audit firm to second tier audit firm, or from second tier audit firm to Big 4

$0=$ no change in classification

-1 = from Big 4 to second tier audit firm, or from second tier audit firm to local audit firm

$+2=$ from Big 4 to local audit firm 
Table 3.1 provides a classification for auditor change types (Big 4/second tier/local) for the considered period from 2006 to 2009. Column 1 shows that one company (1\%) had changed from a local audit firm to a Big 4 audit firm during the considered period. Another 21 (19\%) companies, as represented by column 2, had changed either from a local audit firm to a second tier audit firm or from a second tier audit firm to a Big 4. It is worth noting that about 22 (20\%) of the sample companies had experienced an upgrade change in their audit quality during the considered time period of the study. A total of 68 (62\%) companies had changed their auditors within the same classification of auditor type as shown in column 3. They had experienced par change in their audit quality in terms of brand name. Column 4 indicates that 18 (17\%) of companies had either changed from Big 4 to second tier audit firm or from second tier audit firm to a local audit firm. Column 5 indicates that one company (1\%) had changed from a Big 4 audit firm to a local audit firm. It is worth noting that 19 (18\%) of companies had experienced a downgrade change in their audit quality. Thus, the majority of the auditor-change cases have taken place among the Big 4 audit firms during the considered time period of study, giving an indication that the GCC audit market is dominated by the Big 4 audit firms.

It is worth mentioning that the frequency of auditor change had occurred in 2007 (22\%), 2008 (43\%) and 2009 (31\%). This is due to the learning taking place by the time significance of corporate governance, and the enforcement of implementing the codes of corporate governance that had been taking place surrounding this time period. The start-up of this process begins in the 2007 period and reaches the peak in 2008. These circumstances were a result of the GCC establishing a common market on January $1^{\text {st }}, 2008$. All GCC companies and citizens have no barriers to invest and thus traded in any other GCC country. Consequently, these events have rearranged the alignment of the auditor-client relationships that, in turn, has led to many auditor changes cases in 2008 (Arab Times, 2012).

\section{Regression Model}

This study adopts and modifies DeFond's (1992) model of audit quality. DeFond (1992) reports that there is a possibility of resolving agency problems by combining the auditor characteristics (auditor size, brand name, expertise, and independence) as a construct. These variables are expected to be better measures of audit quality when considering as a group and not individually. For the reasons of performing hypotheses' tests, if each of these variables is a noisy measure of audit quality, then the combination of these variables can minimize the dependent variable's noise by the power of the tests that would have been increased.

The combination of the four audit quality proxies is done by using the Principal Component Analysis's technique. For this purpose, an eigenvalue analysis is utilized and the linear combination is done using the correlation matrix of the variables of interest. Futhermore, this procedure can account for the maximum amount of variance. In order to measure the auditor's ability to resolve agency problems, the 
common factor is utilized. To estimate this model, Multivariate Analysis is applied using Ordinary-Least Square (OLS regression) which is estimated using crosssectional data, for a period of three years spanning one year before the auditor change through one year after the auditor change. The following OLS regression is used by this study:

AQSCORE $=\beta_{0}+\beta_{1}$ FEE + CONTROL VARIABLES $\left(\beta_{1}\right.$ BDE SCORE $+\beta_{2}$ ACE_SCORE $+\beta_{3}$ GOV_OWN $+\beta_{4}$ FAMILY_OWN $+\beta_{5}$ DOMESTIC_OWN $+\beta_{6} L A S S E T+\beta_{7} L E V+\beta_{8} R O A+\beta 9 M G T_{-} C H A N+e$

Where the dependent variable is:

AQ_SCORE= = the principal components linear combination of the four audit

firm's quality measures based on DeFond (1992),

Where the independent variables are:

Test Variable

FEE

Control variables

BDE_SCORE

ACE_SCORE

GOV_OWN

FAMILY_OWN

DOMESTIC_OWN

\section{LASSET \\ LEV \\ $\mathrm{ROA}$ \\ MANG_CHAN}

e
= proportion of firm's revenues to audit firm's total revenues,

= proportion of board of directors' effectiveness,

= proportion of audit committee effectiveness,

= percentage of 5 or more of the ordinary shares held

by the

government and its agencies,

= percentage of 5 or more of the ordinary shares held by a family,

= percentage of 5 or more of the ordinary shares held by domestic corporations,

$=\log _{10}$ of the total assets,

$=$ total debt to total assets,

= return on assets,

= dummy variable, coded " 1 " if there is a change in chairperson,

CEO and other board members and "O" otherwise,

= Error term. 
Since OLS regression is used to test the hypotheses, outliers are detected and handled, assumptions of multicollinearity, normality, heteroscedasticity, linearity, autocorrelation and model specification tests such as Linktest and Ramsey test are also evaluated.

The dependent variable in this study is audit quality AQ SCORE. It is well established by the prior and recent research on auditing that there is no consensus of a single proxy for audit quality, and the available proxies have more than one measurement. It is also worth highlighting that one of the reasons that previous studies have produced conflicting results, is that they use different simple audit quality proxies and/or the binary indicator variables of audit quality. Importantly, one of the more rigorous studies using a complex and comprehensive measurement of audit quality is that conducted by DeFond (1992) in the U.S. data. This study uses a combination of four audit quality surrogates that have a recurring presence in the literature, namely; brand name auditor, auditor size, auditor specialist and auditor independence.

DeFond (1992) reports that a combination of measurement can be used to capture the same underlying construct, namely he auditor's ability to alleviate agency conflicts. Consequently, it is suggested that the combination of these four measurements may provide more information than if they had been individually used. DeFond (1992) also indicates that performing hypotheses testing using each of the auditor characteristics would be considered a noisy measure of the audit quality. Therefore, combining the four measurements may increase the power of the tests that would, subsequently, reduce noise in the independent variable. To the best of the researcher's knowledge, DeFond's (1992) study is the only one that uses the comprehensive combination of four surrogates of audit quality because he concludes that the results obtained by this combined measure are similar to those obtained by using the simple model of brand name. Unlike DeFond's (1992) study that was conducted in U.S., this study is carried out in the GCC setting, which is considered to be a different institutional and audit environment. Accordingly, different results are expected to be reported. Therefore, the similar measurement of the comprehensive combined measure of audit quality is adopted by this study. The four surrogates of audit quality used to construct the combined measure of audit quality have been measured as follows:

\section{Auditor Size}

Auditor size is measured based on the following equation (total client assets audited by the new auditor - the total client assets audited by the old auditor = difference)/ the larger of the old or new audit firm total client assets. The result of this equation will range between -1 and 1 . The positive results indicate an auditor change to a larger auditor. This measurement is considered a good surrogate for audit quality (Chan et al., 2007; DeAngelo, 1981; DeFond et al., 2000; Johnson \& Lys, 1990; Reynolds \& Francis, 2001). 


\section{Brand Name Auditor}

To calculate the switch in the brand name auditor, the following values are given to the classification of quality: "2" = Big 4 firms, "1" = second tier firms and "0" = local firms. In the determining of the rank-ordered variable (-2, -1, 0, 1, \& 2), the following calculation is applied: (the value of the firm subsequent to change - the value of the audit firm prior to the change). Positive numbers indicate "upgrade; an increase in brand name reputation while negative numbers indicate "downgrade;" a decrease. This category enables the model to consider the direction of auditor change. This measure is specifically used by DeFond (1992) and Lee et al. (2004). Importantly, classifying auditors as three categories of quality differentiation is previously used by Bedingfield and Loeb (1974), Burton and Loeb (1967) and Carpenter and Strawser (1971).

\section{Industry-Specialist Auditor}

Industry-specialist auditor variable classifies audit firms as an "industry-specialist auditor" if its market share in the client's industry is $10 \%$ or greater and "nonindustry-specialist auditor." Companies are then coded " 1 " if they have changed from "non-industry-specialist auditor" to an "industry-specialist auditor," "O" if they have experienced no change in industry-specialist and "-1" if they have changed from "industry-specialist auditor" to non-industry-specialist auditor." This measurement is used by DeFond (1992). Further, the measurement of industry-specialist and non-industry-specialist based on the market share in the client's industry is used by several recent and earlier studies (Beasly \& Petroni, 2001; Craswell et al., 1995; DeFond, 1992; Eichenseher \& Danos, 1981; Iskandar et al., 2000; Krishnan et al., 1996; Rhode, Whitesell \& Kelsey, 1974; Sahdan, \& Rasit, 2008; Schiff \& Fried, 1976; Shockely \& Holt, 1983; Williams, 1988; Zeff \& Fossum, 1967).

\section{Auditor Independence}

It is documented by several studies that auditors, in certain circumstances, might fear dismissal by companies that pay a large amount of fees in case they report a breach (DeAngelo, 1981b; DeFond, 1992; Firth, 1985; McKeown et al., 1991). DeFond (1992) documents that fee data are difficult to obtain and/or not available because of its proprietary nature. In order to avoid the weak disclosure of audit fees by companies, some researchers have collected audit fee information directly from the clients, but they received a low response rate, approximately 33\%. (Palmrose, 1982; Simunic, 1980; Wallace, 1984). In the GCC setting, the same circumstances exist because companies operating in the GCC are not required by law to mandatory disclosure of their audit fees. Therefore, DeFond (1992) and Chan et al. (2007) measure the independence of the audit firms as the difference between the ratio of the switching of client firm's revenues to the total revenues of the clients of the old auditor, minus the same ratio for the new auditor. This ratio is bounded by "1" and "-1,' with positive numbers indicating a switch to a more independent audit firm. 
This study adopts the same measurement of DeFond (1992) and Chan et al. (2007) since it has been thought to be a better proxy for audit quality in the environment where audit fees are not disclosed. Auditor independence is calculated using the following formula: (difference between the ratio of the switching of client firm's revenues to the total revenues of the clients of the old auditor - the same ratio for the new auditor). This ratio is bounded by " 1 " and "-1,' with positive numbers indicating a switch to a more independent audit firm. More importantly, audit firm size based on companies' sales has been used as a good quality surrogate because it is suggested that companies' sales are associated with quasi-rents (Chan et al., 2007; DeFond, 1992; Francis \& Wilson, 1988; Johnson \& Lys, 1990).

We also control for the effect of nine agency-related variables on audit quality. As for board of directors' effectiveness score BDE_SCORE, Cassell et al. (2012) have investigated the influence of corporate governance index (independence, meetings, and financial expertise of board and audit committee members) on auditor switch from a Big 4 to a non-Big 4. They concluded that board of directors' effectiveness is related to the auditor-client realignments. In addition, studies on auditor choice have empirically linked auditor choice with board of directors' characteristics (Beasley \& Petroni, 2001; Chen \& Zhou, 2010; Lee et al., 2004; Alzahrani \& Che-Ahmad, 2015). The expected sign for the association of board of directors' effectiveness with audit quality is positive. In terms of audit committee effectiveness ACE_SCORE, the extant research on auditor choice has linked audit committee characteristics and auditor choice (Cassell et al., 2012; Abbott \& Parker, 2000; Archambeault \& DeZoort, 2001; Carcello \& Neal, 2003; Chen \& Zhou, 2010; Lee et al., 2004; Robinson \& Owens-Jackson, 2009). The expected sign for the association of audit committee effectiveness with audit quality is positive.

As for government ownership GOV_OWN, agency theory suggests a negative association with auditor change. Guedhami et al. (2009) document a significantly negative relationship between the government's equity stake and the choice of Big 4 audit firms. Wang et al. (2008) report that small local audit firms are selected by local SOEs. And, there is no difference between central SOEs non-state firms in terms of selecting small local audit firms. Chan et al. (2007) find a negative association between government ownership and auditor size. The expected sign for the association of government ownership with audit quality is negative. In terms of family ownership

FAMILY_OWN, this study uses the agency framework and follows Carey et al. (2000) arguing that agency problems such as self-interest, conflict of interests and goals and information asymmetry can still arise in family businesses. Therefore, agency theory predicts the existence of potential conflict in family business (Fama \& Jensen, 1983). Carey et al. (2000) find that the demand for audit quality is positively associated with the degree of family ownership. This is because of the existence of non-family members and representation on the board of directors. The expected sign for the association of family ownership with audit quality is negative. Regarding domestic corporate ownership DOMESTIC_OWN, the agency costs 
would be reduced in a case when there is an increase in the holdings of the ownerlargest shareholder. Therefore, the controlling owners will be motivated to improve earnings informativeness due to their need in managing earnings for the purpose of alleviating contractual constraints. This circumstance is associated with demanding a higher audit quality (Jensen \& Meckling, 1976). Hiring a high audit quality by the controlling owners is expected to signal a good practice of corporate governance and is indictive of a credible financial reporting from the perspective of the minority shareholders and other investors. Allen and Phillips (2000) empirically report that corporate ownership can reduce the costs of monitoring the alliances or ventures between firms and their substantial shareholders in companies involved in certain business agreements. It is further indicated that higher degrees of technical and organizational and financial resources are provided by domestic investors than those provided by foreign investors (Chibber \& Majumdar, 1999; Djankov \& Hoekman, 2000; Khanna \& Palepu, 2000). The expected sign for the association of domestic corporate ownership with audit quality is positive.

As for the firm size LASSET, Lin and Liu (2009) document that firm size is positively related to the selection of Top-10 audit firms. With regard to the association between firm size and the selection of brand name auditor (Big 4/6/8), Palmrose (1988), Hope et al. (2008), Knechel et al. (2008), Gudhami et al. (2009) find a significantly positive relationship. Further, Wang et al. (2006) find that firm size is negatively associated with the selection of small local audit firms. Cassel et al. (2012) document that firm size is negatively associated with auditor change from Big 4 to non-Big 4 audit firms. However, Lee et al. (2004) report that firm size is positively associated with the change among Big-5, national and local audit firms. Abbott and Parker (2000) find that firm size is positively related to the selection of specialist auditor. Robinson and Owens-Jackson (2009) report a significantly positive association between firm size and the incidence of auditor change. The expected sign for the association of firm size with audit quality is positive. Regarding leverage LEV, DeFond (1992) and Hope et al. (2008) report a significant and positive association. With respect to the association between auditor leverage and auditor size, DeFond (1992) find a significantly positive association. As for audit quality change, Lee et al. (2004) report that leverage is positively associated with the probability of change among Big 4, national and local audit firms. Eichenseher and Shields (1989) the documentation that leverage is positively related to the incidence of a change from non-Big 4 to Big 4 audit firms. With respect to the incidence of auditor change, Woo and Koh (2001) report a significantly positive association between leverage and auditor change.

In terms of the auditor independence, DeFond (1992) find that leverage is positively related to the selection of independent auditor. The expected indication for the relationship between leverage and audit quality is positive. In terms of firm performance $R O A$, Schwartz and Menon (1985) indicate that change in a company's financial condition may produce a change in the desired package of audit services (Schwartz \& Menon, 1985). Woo and Koh (2001) indicate that auditors who are working 
with higher perceived audit and business risks will assign more audit procedures and conservative accounting treatments or if there is still a distressed situation, the incumbent auditor might resign. Moreover, companies with unsound financial positions may select another auditor in the hopes of receiving more favorable audit reports (Citron \& Taffler, 1992; Haskins \& Williams, 1990). Lindahl (1996) reports that one indication of financial distress is a loss which may lead to an auditor change. The expect sign for the link between firm performance and audit quality is positive. With respect to management change MANG_CHAN, it is indicated that a new management team charged with the responsibility of bringing about a corporate recovery may view the selection of reporting methods as a means for influencing the decisions of suppliers of capital, by portraying corporate performance in a more favorable light, and thus, may be facilitated by finding an auditor willing to sanction those methods advocated by management (Burton \& Roberts, 1967; Carpenter \& Strawser, 1971; Hudaib \& Cooke, 2005; Lurie, 1977; Schwartz \& Menon, 1985; Woo \& Koh, 2001). Beatttie and Fearnley (1998) provide further evidence vis-a-vis management change. They have reported that 35\% of auditor change companies cite top management changes as a reason for switching. Empirically, Robinson and Owens-Jackson (2009) report a significantly positive association between management change and the propensity of auditor change. Carcello \& Neal (2003) report a significantly positive relationship between management change and the auditor change, after receiving and ongoing report concern. The expected indication for the relationship between management change and audit quality is positive.

\section{RESULTS AND DISCUSSIONS Descriptive Statistics}

Table 4.1 and Table 4.2 display a statistical description of the continuous and dichotomous variables used in the regressions for the two-year periods; before $\left(t^{-}\right)$ and after $\left(t_{1}\right)$ the auditor selection. 
Table 4.1. Descriptive Statistics of Continuous Variables

Variables $\quad\left(t_{-} ; \mathrm{n}=104 ; t_{1}: \mathrm{n}=108\right)$

\begin{tabular}{|c|c|c|c|c|c|}
\hline & Mean & Median & Min & Max. & Std.Dev \\
\hline \multicolumn{6}{|l|}{$\begin{array}{l}\text { Panel A: Independent } \\
\text { Variables }\end{array}$} \\
\hline FEE _t- (decimal) & 0.12 & 0.005 & 0.00 & 1.00 & 0.27 \\
\hline FEE $t_{1}$ (decimal) & 0.09 & 0.004 & 0.00 & 1.00 & 0.25 \\
\hline BDE_SCORE _t ${ }_{-1}$ (decimal) & 0.58 & 0.57 & 0.29 & 0.86 & 0.16 \\
\hline BDE_SCORE_ $t_{1}$ (decimal) & 0.56 & 0.57 & 0.14 & 0.86 & 0.15 \\
\hline ACE _ SCORE _t ${ }_{-1}$ (decimal) & 0.81 & 0.83 & 0.33 & 1.00 & 0.18 \\
\hline ACE _ SCORE _ $t_{1}$ (decimal) & 0.82 & 0.83 & 0.33 & 1.00 & 0.16 \\
\hline GOV_OWN_t-1 $(\%)$ & 7.47 & 00.00 & 00.00 & 74.30 & 15.00 \\
\hline GOV_OWN_t $t_{1}(\%)$ & 8.03 & 00.00 & 00.00 & 74.30 & 16.12 \\
\hline FAMILY-OWN $t_{-1}(\%)$ & 11.21 & 00.00 & 00.00 & 82.77 & 17.24 \\
\hline FAMILY-OWN_t $t_{1}(\%)$ & 10.71 & 00.00 & 00.00 & 82.77 & 16.72 \\
\hline DOMESTIC OWN $t_{-1}(\%)$ & 23.47 & 0.140 & 00.00 & 100.00 & 25.54 \\
\hline DOMESTIC_OWN_ $t_{1}(\%)$ & 26.17 & 14.90 & 00.00 & 100.00 & 28.68 \\
\hline LASSET_ $t_{-1}(\$ \mathrm{mil})$ & 1.17 & 0.14 & 0.002 & 34.38 & 4.78 \\
\hline LASSET_ $t_{1}(\$ \mathrm{mil})$ & 1.15 & 0.14 & 0.002 & 34.38 & 4.72 \\
\hline $\mathrm{ROA}_{-} t_{-}$ & 9.91 & 9.20 & -12.51 & 42.46 & 10.38 \\
\hline $\mathrm{ROA}{ }_{-} t_{1}$ & 8.18 & 8.27 & -17.44 & 35.08 & 10.22 \\
\hline LEV _ $t_{-1}$ & 21.00 & 13.21 & 0.00 & 96.13 & 21.89 \\
\hline LEV _ $t_{1}$ & 19.76 & 12.34 & 0.00 & 95.41 & 21.38 \\
\hline
\end{tabular}

Panel B: Dependent Variables

\begin{tabular}{|c|c|c|c|c|c|}
\hline AUD SIZE $t_{-}$ & 0.08 & 0.10 & -0.86 & 1.00 & 0.29 \\
\hline AUD SIZE $t_{1}$ & 0.09 & 0.11 & -0.86 & 1.00 & 0.30 \\
\hline AUD _INDE ${ }_{-} t_{-}$ & 0.03 & -0.00 & -0.99 & 0.99 & 0.32 \\
\hline AUD_INDE_ $t_{1}$ & 0.03 & -0.00 & -0.99 & 0.99 & 0.32 \\
\hline $\mathrm{AO}{ }_{-} \mathrm{SCORE}{ }_{-} t_{1}$ & 2.35 & 0.94 & 0.00 & 26.63 & 3.82 \\
\hline AO SCORE $t_{1}$ & 2.31 & 0.99 & 0.00 & 26.57 & 3.78 \\
\hline
\end{tabular}

As reported in Table 4.1, the FEE mean (median) values for the year prior to the auditor selection $\left(t_{1}\right)$ and the year after the auditor selection $\left(t_{1}\right)$ are $0.12(0.005)$ and 0.09 (0.004), respectively. On average, this suggests that there is a decreased tendency in the audit fees for the period surrounding the auditor selection. Inclusion of several client firms with large percentages of audit fees causes a large difference between the mean and median of the audit fees. The mean (median) values of the 
effectiveness of board of directors ( $\left.B D E_{-} S C O R E\right)$ for the periods before $\left(t_{-}^{-}\right)$and after the auditor selection $\left(t_{1}\right)$ are $0.58(0.57)$ and 0.56 (0.57), respectively. This suggests that, on average, there is a decrease in the degree of board effectiveness in the year subsequent to the auditor selection $\left(t_{1}\right)$ compared with the year prior to the auditor selection $\left(t_{-1}^{-}\right)$, although the median board of directors' effectiveness is identical for both the pre--auditor selection year $\left(t_{-1}^{-}\right)$and the subsequent year after the selection is made $\left(t_{1}\right)$. With respect to audit committee effectiveness (ACE_SCORE), the mean (median) values for the period prior to the auditor $\left(t_{-}^{-}\right)$and the period subsequent to the auditor selection $\left(t_{1}\right)$ are $0.81(0.83)$ and $0.82(0.83)$, respectively. This implies that there is an increase in the level of audit committee effectiveness in the year subsequent to the auditor selection $\left(t_{1}\right)$ compared with the pre-auditor selection year $\left(t_{-1}^{-}\right)$, in spite of the fact that the median audit committee effectiveness remains the same in the considered periods $\left(t-\frac{1}{1} t_{1}\right)$.

With regard to the government ownership (GOV_OWN), the mean values for the year prior to the auditor selection $\left(t_{-}^{-}\right)$and for the year subsequent the auditor selection $\left(t_{1}\right)$ are $7.47 \%$ and $8.03 \%$, respectively, with identical median values of 0.00 . The minimum (maximum) values of the government ownership for the both periods before $\left(t_{1-}^{-}\right)$and after the auditor selection $\left(t_{1}\right)$ are $0.00(74.30 \%)$ and $0.00(74.30 \%)$, respectively. These statistics suggest that there is an increase in the percentage of government owned companies in the two-year periods surrounding the auditor selection $\left(t_{-1} \& t_{1}\right)$. The maximum values of the government ownership in the GCC indicate that there is a dominance presence of the government owning high percentages of companies' shares up to $74.30 \%$. The very large difference between the mean and median of the government ownership is due to the inclusion of several client firms with very large government ownership.

In terms of the FAMILY_OWN, the mean values for the both periods; before $\left(t_{-1}^{-}\right)$ and after $\left(t_{1}\right)$ the successor auditor selection are 11.21 and 10.71, respectively with equal median values of 0.00 . The minimum (maximum) values for the both periods before $\left(t_{-1}\right)$ and after the successor auditor selection $\left(t_{1}\right)$ are $0.00(82.77 \%)$ and 0.00 (82.77\%), respectively. The statistics of mean values show that there is a decrease in the proportion of family ownership in the surrounding period of auditor selection. The minimum (maximum) values exhibit that there is a high presence of family ownership among GCC companies reaching up to $82.77 \%$. The very large difference between the mean and median of the family ownership is because of the inclusion of several client firms with very high percentages of family ownership. 
With respect to the DOMESTIC_OWN, the mean (median) values for the year of the predecessor auditor $\left(t_{-}{ }_{1}\right)$ and the year subsequent the successor auditor $\left(t_{1}\right)$ are $23.47 \%$ (0.14\%) and 26.17\% (14.90), respectively. The minimum (maximum) values of the domestic corporate ownership for the both periods; before $\left(t_{-}^{-}\right)$and after $\left(t_{1}\right)$ the successor auditor are 0.00 (1.00) and 0.00 (1.00), respectively. The statistics of the domestic corporate ownership mean (median) values portray that there is an increased tendency for domestic corporate ownership in the years surrounding the auditor selection. There is also an indication shown by the minimum (maximum) statistics that there is a high existence of the domestic corporations owing high percentages of GCC companies. Among the three dominant groups; namely government, family and the domestic corporations, the latter group has the highest dominant presence in the GCC market followed by family and, then, the government. It is also worth noting that the very large variation between the mean and median values of the domestic corporate ownership is due to the fact that there are several companies with very large domestic corporate ownership that have been included in the sample. This inclusion does not result in large outliers as can be seen in the following section.

As for LASSET, the mean (median) values for the both periods; the year of the predecessor $\left(t^{-}\right)$and the subsequent year of the successor $\left(t_{1}\right)$ are $\$$ mil 1.17 (0.14) and \$ mil 1.15 (0.14), respectively. This indicates that the firm size in GCC countries increases in the period surrounding the auditor selection. And, the difference between the mean and median values is because of including several client firms with large sizes. As for the $R O A$, the mean (median) values for the both periods; before $\left(t^{-}\right)$and after $\left(t_{1}\right)$ the auditor selection are 9.91 (9.20) and 8.18 (8.21), respectively. There is a decrease, on average, in GCC companies' firm performance for the period surrounding the auditor selection. With respect to the Lev, the mean (median) values for the year of the predecessor $\left(t^{-}\right)$and the year subsequent to the successor $\left(t_{1}\right)$ are 21.00 (13.21) and 19.76 (12.34), respectively. The leverage mean indicates that there is a decreased trend in the debt level of GCC companies in the time surrounding the auditor selection.

As depicted by Table 4.2, the number of companies with MGT_CHANGE is relatively small compared with non-management change companies in year $t_{1_{1}}[29$ $(28 \%)]$ and is closer to the half in year $t_{1}[49(45 \%)$. Comparing the management change between the year of the predecessor auditor $\left(t^{-}\right)$and the year subsequent the successor auditor $\left(t_{1}\right)$, the management change in year $t_{1}$ is higher than the management changes in year $t^{-}$by $41 \%$, suggesting that the event of management change in the period subsequent to the auditor selection can explain more about the auditor selection, and quality-differentiated audits. 
Khaled Salmen Aljaaidi · Shamharir Bin Abidin · Waddah Kamal Hassan Audit Fees and Audit Quality: Evidence from Gulf Cooperation Council Region

Table 4.2. Descriptive Statistics (Percentage) for Dummy Variables

\begin{tabular}{lccc} 
& $t_{-}: \mathrm{n}=104 ; t_{1}: \mathrm{n}=108$ & Totals \\
\hline Dichotomous Variables & 1 & 0 & \\
\hline MGT_CHANGE _t ${ }_{-}{ }_{1}$ & 29 & 75 & 104 \\
& $(28 \%)$ & $(72 \%)$ & $100 \%$ \\
MGT_CHANGE _t & 49 & 59 & 108 \\
& $(45 \%)$ & $(55 \%)$ & $100 \%$
\end{tabular}

Table 4.3 presents the descriptive statistics for the number of the dominant group ownership, namely; government and its agencies, family, and domestic corporate owners.

Table 4.3. GCC Ownership Structure of the Sample Companies

\begin{tabular}{|c|c|c|c|c|c|c|c|c|}
\hline \multirow[t]{2}{*}{ Ownership Type } & \multicolumn{2}{|c|}{$\begin{array}{l}\text { Government } \\
\text { Ownership }\end{array}$} & \multicolumn{2}{|c|}{$\begin{array}{l}\text { Family } \\
\text { Ownership }\end{array}$} & \multicolumn{2}{|c|}{$\begin{array}{l}\text { Domestic } \\
\text { Corporate } \\
\text { Ownership }\end{array}$} & \multicolumn{2}{|c|}{$\begin{array}{l}\text { Foreign- } \\
\text { Corporate } \\
\text { Ownership }\end{array}$} \\
\hline & $t_{1}$ & $t_{1}$ & $t_{-}$ & $t_{1}$ & $t_{1}$ & $t_{1}$ & $t_{-1}$ & $t_{1}$ \\
\hline $\begin{array}{l}\text { Number of } \\
\text { dominant groups } \\
\text { who own } 5 \% \text { or } \\
\text { more }\end{array}$ & $\begin{array}{c}37 \\
(36 \%)\end{array}$ & $\begin{array}{c}38 \\
(35 \%)\end{array}$ & $\begin{array}{c}51 \\
(49 \%)\end{array}$ & $\begin{array}{c}49 \\
(45 \%)\end{array}$ & $\begin{array}{c}67 \\
(64 \%)\end{array}$ & $\begin{array}{c}72 \\
(67 \%)\end{array}$ & $\begin{array}{c}7 \\
(0.07 \%)\end{array}$ & $\begin{array}{c}5 \\
(0.05 \%)\end{array}$ \\
\hline $\begin{array}{l}\text { Number of } \\
\text { companies with } 0 \% \\
\text { ownership of the } \\
\text { dominant groups }\end{array}$ & $\begin{array}{c}67 \\
(64 \%)\end{array}$ & $\begin{array}{c}70 \\
(65 \%)\end{array}$ & $\begin{array}{c}53 \\
(51 \%)\end{array}$ & $\begin{array}{c}59 \\
(55 \%)\end{array}$ & $\begin{array}{c}37 \\
(36 \%)\end{array}$ & $\begin{array}{c}36 \\
(33 \%)\end{array}$ & $\begin{array}{c}97 \\
(93 \%)\end{array}$ & $\begin{array}{c}103 \\
(95 \%)\end{array}$ \\
\hline Total & $\begin{array}{c}104 \\
(100 \%)\end{array}$ & $\begin{array}{c}108 \\
(100 \%)\end{array}$ & $\begin{array}{c}104 \\
(100 \%)\end{array}$ & $\begin{array}{c}108 \\
(100 \%)\end{array}$ & $\begin{array}{c}104 \\
(100 \%)\end{array}$ & $\begin{array}{c}108 \\
(100 \%)\end{array}$ & $\begin{array}{c}104 \\
(100 \%)\end{array}$ & $\begin{array}{c}108 \\
(100 \%)\end{array}$ \\
\hline
\end{tabular}

Table 4.3 shows that there is no variation in the foreign-controlled ownership which justifies the reason for excluding such type of the ownership from Model 2. There is a lack of corporate governance framework in the GCC countries which leads to the absence of foreign investors who would be likely to apply good corporate governance practices (INSEAD, 2010; AL Majlis, The GCC Board Directors Institute, 2009).

The highest number of ownership type is the domestic corporate shareholder who dominates the majority of the companies in GCC ( $t_{-1}: 67$ (64\%); $t_{1}=72$ (67\%). This follows in line with what has been found by Claessens et al. (2000), namely that domestic 
corporate is among the largest group of blockholders in many emerging markets. The second highest dominant ownership in number is the family shareholders $\left(t_{-1} 51\right.$ (49\%); $t_{1:} 49$ (45\%). Government ownership is ranked as the third dominant group in GCC market ( $t_{-1} 37$ (36\%); $t_{1:} 38$ (35\%).

The preponderance of positive mean (median) changes in the dependent variables (name-brand, auditor size, independence, expertise and the combined measure) indicates that the general change was to larger, higher quality auditors. The difference in the mean (median) values for the dependent variables between the prior year to the auditor selection $\left(t_{-1}\right)$ and the subsequent year to the auditor selection $\left(t_{1}\right)$ is due to the dropping of five and one outliers, respectively. The very large difference in terms of value and sign between the mean and median of the auditor independence is because of the inclusion of several client firms with very large auditor independence. Both models are generally constant over the two measurements dates, and they show almost equivalent values for the descriptive analysis.

The Principal Component Analysis (PCA) using the varimax rotation is applied to combine the four variables, namely; brand-name auditor, auditor size, auditor independence and auditor expertise. Extracting common factors out of a set of variables can be done using the factor analysis tool, PCA. An eigenvalue analysis is utilized and the linear combination is done using the correlation matrix of the variables of interest. Further, this procedure can account for the maximum amount of variance. The common factor is used in the hypotheses tests as a measure of the audit quality. For all the three variables (brand-name, independence and expertise), the overall values of Kaiser-Meyer-Olkin were ( $t_{-}:$. 574) in the predecessor year and $(t:$.578) in the subsequent year to the successor, exceeding the recommended value of .50 (Hair et al., 2010). The Bartlett test was highly significant in both periods ( $t_{1}^{-}: p=$ $\left..00 ; t_{1}: p=.00\right)$. This indicates the degree of the appropriateness of the factor analysis in a manner that provides for the statistical probability that the correlation matrix has significant correlations among at least some of the variables (Hai et al., 2010). These suggest that the assumptions of factor analysis were met.

The PCA revealed the presence of two factors or components loading with two eigenvalues exceeding one for the both periods $\left(t_{1} \& t_{1}\right)$. A total of three variables (brand-name, independence and expertise) were loaded on the first factor with factor loadings between .869 and .676 in the $t^{-}$and between .865 and .660 in year $t_{1}$. And, the fourth variable, auditor size, was loaded as only one variable on the second factor with factor loadings of 892 in year $t_{1}$ and .882 in year $t_{1}$. It is worth noting that the first three audit quality surrogates (brand name, independence and expertise) have been combined under one component to reflect the common factor measuring the auditors' ability to alleviate agency conflicts. In the same regard, auditor size has been extracted as a second factor to act as a surrogate variable of audit quality that is representative of that factor. Economists indicate that market participants may come out with proxies measuring quality services when they are involved in qualitydifferentiated marketplaces (Barzel, 1982). 
Although it is still a problematic giving a specified definition of audit quality, this result suggests that, in GCC countries, the audit quality has two primary definitions, but interlinked sources of demand for audit quality: (1) a combined measure of auditor characteristics, namely; brand-name, independence and expertise, and (2) auditor size. In terms of the first definition, the combined measure, for this type of audit service, represents the information demand (Dopuch and Simunic, 1982) and insurance demand (Beattie \& Fearnley, 1995). The information demand signals the quality of the management's representations concerning financial performance. The insurance demand stems from investors' desire to indemnify themselves from financial losses via the auditor's professional liability exposure. Importantly, DeFond (1992) has reported that the combination measure captures the same underlying construct, namely the auditor's ability to alleviate agency conflicts. The combined variables are expected to be a good measure of audit quality when considered as a group and not individually, in a manner that they would increase the power of the tests by reducing noise in the dependent variable. Further, for the purposes of obtaining a greater construct validity and a power of generalization, it is advised to use a combination of several proxies rather than a single proxy (Nunnaly and Bernstein, 1994). This is due to the fact that these variables act in a complementary mode which might explain the conflicting results reported by the previous studies, as they consider each variable in isolation from the others, ignoring the point that the effectiveness of a single variable depends on the others.

As for the auditor size, this type of service reflects the agency demand which is closely related to the information demand through which auditing services is required in order to increase the credibility of the financial statements and their reliability as a monitoring device (DeFond, 1992; Francis \& Wilson, 1988). This single surrogate variable, auditor size, has a factor loading that is substantially higher than all other factor loadings in the both periods $\left(t_{1}{ }_{1} \& t_{1}\right)$, but, as shown by the anti-image matrices, the MSA value is lesser than 0.5 , supporting its deletion from the analysis in year $t^{-}$. Using this single variable as a representative of the audit quality may cause some problems, (Hair et al., 2010): (1) as it does not address the issue of measurement error encountered when using single measures, and (2) it runs the risk of potentially misleading results by selecting only a single variable to represent, perhaps, a more complex set of results. Therefore, this variable has been excluded, and the loadings of the combined measure of audit quality have been recalculated.

As shown in Table 4.4, the latent root criterion for number of factors to derive would indicate that there was one component loading to be extracted with eigenvalue with more than one for the both periods $\left(t_{1}^{-}: 1.83 ; t_{1}: 1.81\right)$ and with a simple structure. This factor captures $61.01 \%$ and $60.39 \%$ of the total variance in the variables for the both periods before $\left(t_{-}\right)$and after $\left(t_{1}\right)$ the auditor selection, respectively. The factor solution has explained more than half of the original variables' variance, so the communality values for the both periods $\left(t_{1}{ }_{1} \& t_{1}\right)$ are higher than 0.50 . The Kaiser- 
Meyer-Olkin values were identical for the both periods; before $\left(t_{-}^{-}: 58 ; n=104\right)$ and after $(t: .58 ; n=108)$ the auditor selection, exceeding the recommended value of .50 .

Also, the sample size for both periods exceeds the preferably number, which is 100 or larger (Hair et al., 2010). The Barlett's tests of sphericity were highly significant for both periods $\left(t^{-}: p=.00 ; t_{1}: p=.00\right)$, supporting the factorability of the correlation matrix. In addition, an examination of the measure of sampling adequacy for each item fall within the acceptable range ( $t_{1}: .55-.62 ; t_{1}: .55$ - .62) (Hair et al., 2010). At this stage of statistical analysis of the PCA, the assumptions of factor analysis were met. The factor loadings are between .71 and .87 in year $t_{1}$ and between .70 and .87 in year $t_{1}$. These loadings were greater than .30 which is considered to meet the minimum level required (Hair et al., 2010). Reliability (Cronbach's Alpha) values for this factor are .65 in year $t_{1}$ and .64 in year $t_{1}$. These values fall within the accepted range (Hair et al., 2010). Since this factor measures the ability of auditors alleviating the agency conflicts, and its original name is retained.

Table 4.4. Principal Component and Reliability Analyses on Audit Quality

Variables

\begin{tabular}{lcc}
\hline Name-Brand Auditor & .87 & .87 \\
Auditor Independence & .75 & .75 \\
Auditor Expertise & .71 & .70 \\
Eigenvalue & 1.83 & 1.81 \\
\% of variance & 61.01 & 60.39 \\
Kaiser-Meyer-Olkin (KMO) & .58 & .58 \\
\hline Bartlett's Test of Sphericity: Approx Chi-Square & 57.41 & 56.75 \\
df & 3 & 3 \\
Sig & .00 & .00 \\
Cronbach's Alpha $(\alpha)$ & .65 & .64 \\
\hline
\end{tabular}

It is worth highlighting that the combined measure of audit quality in DeFond (1992)'s sole study, a U.S based-research, is comprised of four surrogates, namely; brand-name auditor, auditor independence, auditor size and auditor expertise. This suggests that, in the U.S setting, the audit quality as one bundle or as an aggregation measurement encompasses these four auditor characteristics. Following DeFond (1992)'s combined measure of audit quality in the GCC context, a different result has been reported. It consists of only brand-name auditor, auditor independence and auditor expertise. The difference in the structure of the combined measure of audit quality between U.S and GCC countries could be attributed to differences which exist in the institutional frameworks, audit and business environments, and culture. 
Khaled Salmen Aljaaidi · Shamharir Bin Abidin · Waddah Kamal Hassan Audit Fees and Audit Quality: Evidence from Gulf Cooperation Council Region

This study uses the correlation matrix, variance inflation factor (VIF) and tolerance (1/VIF) as examinations identifying the possible existence of multicollinearity.

Table 4.5. Correlation Matrix of Independent Variables for the Two-year Period (t- $\left.{ }_{1} \& t_{1}\right)$

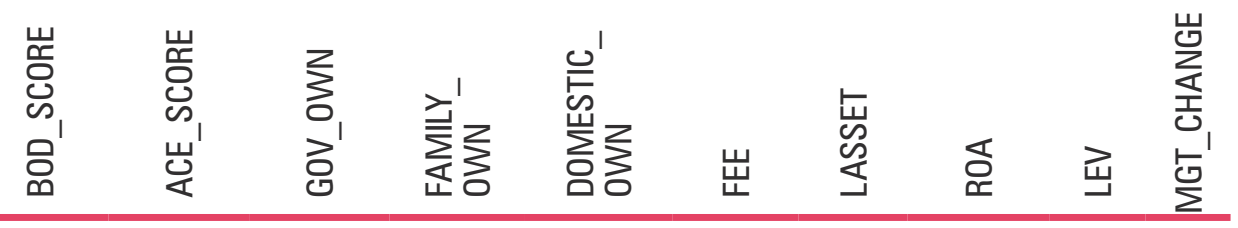

\begin{tabular}{|c|c|c|c|c|c|c|c|c|c|c|}
\hline Panel A: Year t- ${ }_{1}$ & & & & & & & & & & \\
\hline BDE_SCORE & 1 & & & & & & & & & \\
\hline ACE _ SCORE & $.203^{*}$ & 1 & & & & & & & & \\
\hline GOV_OWN & .180 & .069 & 1 & & & & & & & \\
\hline FAMILY_OWN & -.061 & .023 & $-.247^{*}$ & 1 & & & & & & \\
\hline DOMESTIC_OWN & $.276^{* *}$ & .085 & $-.226^{* *}$ & $-0.158^{*}$ & 1 & & & & & \\
\hline FEE & -.023 & -.056 & .096 & .076 & $-.259 * *$ & 1 & & & & \\
\hline LASSET & $-.360^{*}$ & -.156 & $.197^{*}$ & $-.229^{*}$ & $-.221^{*}$ & $.424^{* *}$ & 1 & & & \\
\hline ROA & .021 & -.104 & $.205^{*}$ & .012 & $-.009^{*}$ & $.280^{* *}$ & $.198^{*}$ & 1 & & \\
\hline LEV & .089 & .105 & $-.230^{*}$ & $.254^{* *}$ & .102 & -.157 & -.074 & -.172 & 1 & \\
\hline MGT CHANGE & $.282^{* *}$ & -.076 & .132 & .066 & .075 & -.074 & .030 & .080 & .064 & 1 \\
\hline Panel B: Year $t_{1}$ & & & & & & & & & & \\
\hline BDE _ SCORE & 1 & & & & & & & & & \\
\hline ACE _ SCORE & .016 & 1 & & & & & & & & \\
\hline GOV_OWN & .137 & $.163^{*}$ & 1 & & & & & & & \\
\hline FAMILY_OWN & -.001 & -.055 & $-.253^{* *}$ & 1 & & & & & & \\
\hline DOMESTIC_OWN & $.193^{*}$ & .026 & $-.253^{* *}$ & $-.196 * *$ & 1 & & & & & \\
\hline FEE & -.057 & -.107 & -.006 & -.072 & $-.213^{*}$ & 1 & & & & \\
\hline LASSET & -.170 & $-.250 * *$ & $.245^{*}$ & $-.215^{* *}$ & $-.288 * *$ & $.315^{* *}$ & 1 & & & \\
\hline ROA & -.029 & -.016 & $.195^{*}$ & .028 & -.050 & .100 & .105 & 1 & & \\
\hline LEV & .127 & .007 & $-.155^{*}$ & .148 & .162 & -.174 & .037 & $-.375^{* *}$ & 1 & \\
\hline MGT_CHANGE & -.067 & -.016 & .091 & .157 & -.056 & .097 & -.047 & -.003 & .003 & 1 \\
\hline
\end{tabular}


As shown by Table 4.5, the correlation matrixes verify that no multicollinearity exists among the variables in both models, pre-auditor selection $\left(t_{1-}\right)$ and post-auditor selection $\left(t_{1}\right)$, as none of the variables correlates above 0.90. All the variables have a correlation of equal to or less than .424 in $t-1$ and .375 in $t$. With respect to the VIF and tolerance, multicollinearity is not a problem in this study for both periods $\left(t-{ }_{1} \&\right.$ $t_{1}$ ) since tolerance values are higher than .10 and VIF values are lesser than 10 (Hair et al., 2010) as shown in Table 4.6.

Table 4.6. Multicollinearity Statistics of Assessing VIF and Tolerance Values

\begin{tabular}{|c|c|c|c|c|}
\hline \multirow{2}{*}{ Independent Variables } & \multicolumn{2}{|l|}{ VIF } & \multicolumn{2}{|c|}{ Tolerance (1/VIF) } \\
\hline & $t_{-1}$ & $\mathrm{t}_{1}$ & $\mathrm{t}_{-1}$ & $\mathrm{t}_{1}$ \\
\hline FEE & 1.46 & 1.22 & .686 & .821 \\
\hline \multicolumn{5}{|l|}{ Control Variables } \\
\hline BDE_SCORE & 1.61 & 1.17 & .622 & .856 \\
\hline ACE_SCORE & 1.10 & 1.17 & .906 & .853 \\
\hline GOV_ OWN & 1.43 & 1.54 & .699 & .649 \\
\hline FAMILY_OWN & 1.31 & 1.37 & .764 & .728 \\
\hline DOMESTIC_OWN & 1.38 & 1.42 & .723 & .704 \\
\hline LASSET & 1.70 & 1.52 & .587 & .660 \\
\hline ROA & 1.19 & 1.23 & .837 & .812 \\
\hline LEV & 1.20 & 1.34 & .831 & .749 \\
\hline MGT CHANGE & 1.16 & 1.00 & .859 & .928 \\
\hline
\end{tabular}

\section{Multivariate Results}

Ordinary-Least Square (OLS) was used to evaluate the level of effect of the hypothesized variables on the decision of hiring a differentiated-audit quality using STATA. 
Khaled Salmen Aljaaidi · Shamharir Bin Abidin · Waddah Kamal Hassan Audit Fees and Audit Quality: Evidence from Gulf Cooperation Council Region

Table 4.7. OLS Analysis Results-Auditor Selection (Model 2)

\begin{tabular}{|c|c|c|c|c|c|c|c|}
\hline \multirow[t]{2}{*}{ Variables } & \multirow[t]{2}{*}{ Expected Sign } & \multicolumn{3}{|c|}{$\begin{array}{l}\text { Pre-Auditor-Selection } \\
\text { Model } 2_{a}\left(t-{ }_{1}\right)\end{array}$} & \multicolumn{3}{|c|}{$\begin{array}{l}\text { Post-Auditor-Selection } \\
\text { Model } 2_{b}\left(t_{1}\right)\end{array}$} \\
\hline & & Coef. & $t$ & $P>|\mathrm{t}|$ & Coef. & $t$ & $P>|\mathrm{t}|$ \\
\hline \multicolumn{8}{|l|}{ Test variable } \\
\hline FEE & + & 0.41 & 3.70 & 0.000 & 0.36 & 3.65 & 0.000 \\
\hline \multicolumn{8}{|l|}{ Control variables } \\
\hline BDE_SCORE & + & -0.31 & -0.43 & 0.666 & 0.73 & 1.16 & 0.247 \\
\hline ACE_SCORE & + & 0.13 & 0.25 & 0.803 & -0.04 & -0.07 & 0.945 \\
\hline GOV_OWN & - & 0.07 & 0.50 & 0.621 & 0.11 & 0.77 & 0.444 \\
\hline FAMILY_OWN & + & 1.07 & 1.83 & 0.070 & 1.46 & 2.40 & 0.018 \\
\hline DOMESTIC_OWN & + & 0.99 & 2.44 & 0.017 & 0.73 & 2.02 & 0.046 \\
\hline LASSET & + & 0.03 & 0.20 & 0.843 & 0.12 & 0.12 & 0.320 \\
\hline ROA & + & -0.03 & -3.03 & 0.003 & -0.02 & -2.65 & 0.009 \\
\hline LEV & + & -0.002 & -0.44 & 0.664 & -0.01 & -1.22 & 0.225 \\
\hline MGT_CHANGE & + & 0.43 & 2.02 & 0.046 & -0.02 & -0.11 & 0.910 \\
\hline Adjusted $R^{2}$ & & & 14.38 & & & 14.04 & \\
\hline Model F-stat. & & & 2.73 & & & 2.75 & \\
\hline$P$-value & & & 0.006 & & & 0.005 & \\
\hline No. of Observations & & & 104 & & & 108 & \\
\hline
\end{tabular}

Bold $=$ significance at $1 \%, 5 \%$ and $10 \%$

Table 4.7 indicates the estimated model coefficients, the associated significant test results, the adjusted $R^{2}$ and the $F$-values for the both models; before $\left(t_{-}{ }_{1}\right)$ and after $\left(t_{1}\right)$ the auditor selection. In particular, Table 7.8 portrays the comparative results of the OLS regressions for each of the two-time periods examined $\left(t_{1} \& t_{1}\right)$ using the principal components combined dependent variable and that of audit quality. These two periods encompass both sides of the year of the auditor selection. The F-value for each year $\left(t_{1} \& t_{1}\right)$ surrounding the auditor selection is statistically significant at the $1 \%$ level, indicating that the overall model can be interpreted. The adjusted $R^{2}$ for the two-year periods; the year of the predecessor auditor $\left(t^{-}\right)$and the subsequent year 
to the auditor selection $\left(t_{1}\right)$ are $14.38 \%$ and $14.04 \%$, respectively. The statistics show that the pre-auditor selection model $t_{-1}$ has explained $14.38 \%$ of the total variance in the audit quality and the post-auditor selection model $t_{1}$ has explained $14.04 \%$ of this variance. This indicates a moderately good fit and comparable to the $R^{2}$ in the study of DeFond (1992) and higher than the $R^{2}$ in the other studies used indicating an individual audit quality surrogate (Abbott \& Parker, 2000; Chan et al., 2007). The adjusted $R^{2}$ s indicate that the period of time surrounding the auditor selection $\left(t^{-}\right.$ $\& t_{1}$ ) provides a good explanatory power for the auditor selection behavior, which suggests that managers may react and anticipate agency conflict changes when they choose new auditors.

Surrounding the two-year periods of the study; before $\left(t^{-}\right)$and after the auditor selection $\left(t_{1}\right)$, the largest $t$-statistics in the period prior to the auditor selection $\left(t^{-}\right)$ were 3.70 ( $p$-value < 0.00), -3.03 ( $p$-value < 0.01), 2.44 ( $p$-value < 0.05), 2.02 ( $p$-value $<0.05$ ), and 1.83 ( $p$-value $<0.10$ ) which are for audit fees. This is consistent with the conjecture of the agency theory, and this study reports a significant positive association between FEE and AQ_SCORE in either period ( $t_{-}^{-}: p$-value $=0.000 ; t_{1}$ : $p$-value $=0.000)$. This significant association is comparable in the year prior $(t$ $\left.{ }_{1}\right)$ and subsequent $\left(t_{1}\right)$ to the auditor selection, indicating that GCC client firms select higher audit quality in reaction to and in anticipation of changes in the audit fees. Thus, this result gives support to hypothesis $H_{1}$. This result is consistent, empirically, with Che Ahmad et al. (2006), Francis (1984), Nazri et al. (2012b), and Pong and Wittengton (1994). One possible interpretation for this result is that, as shown by Table 7.1, 62\% of the auditor changes have been taken place among Big 4 audit firms, indicating that this group of auditors dominates the audit market of GCC countries, and they charge fee premium.

\section{CONCLUSIONS AND IMPLICATIONS \\ Conclusion}

The objective of this study is to identify the association of audit fees with audit quality among listed companies in the GCC region. A total of 104 and 108 non-financial companies listed on the GCC stock markets for the periods preceding and subsequent to the event, respectively, over the period 2005-2010 were studied. A quantitative approach was applied to answer a specific hypothesis developed for the auditor selection model. The results show that the relationship between audit fees and audit quality is significant and positive. This association is consistent with the prediction of agency theory. This result is also consistent, empirically, with Che Ahmad et al. (2006). This study contributes to the corporate governance and auditing literature by providing an initial empirical link between audit fees and the control variables of corporate governance mechanisms (board of directors' effectiveness, audit committee effectiveness, and ownership structure), the audit-specific characteristic, and firmspecific characteristics with auditor selection decision in several ways: First, this study adds to the recent literature by researching and associating audit fees and audit 
quality. To the best of the researcher's awareness, no empirical evidence is available that has linked audit fees and audit quality. Second, as a methodological contribution, the present study addresses audit fees, which have not been examined empirically with the framework of auditor selection based on DeFond's (1992) study. Based on the suggestions of agency theory, different levels of audit fees may lead to a variation in the demand for audit quality (Fama \& Jensen, 1983; Jensen \& Meckling, 1976; Wallace, 1980, 1987). Woo and Koh (2001) document that audit fee has been suggested as a relevant determinant in explaining variation in the demand for audit quality.

Limitations of the study lie, first, on the auditor choice model where the model is developed focusing on establishing a relationship between the audit fees and audit quality. Although a statistically significant association is found, implication of this research design is that the auditor selection model is only able to demonstrate an association and not a causal relationship. Second, the audit fees and audit quality data in this study covers only three years-the period spanning 2005-2010-which may not be generalized for other before-and-after periods. Generalizing the results of this study to other years should be seen with some attentiveness. Third, the quality of the results can be judged based on the quality of the sample data. Our sample is designed based on certain criteria which indicates the possibility of excluding some major auditor-change companies from the sample. Therefore, the results are valid only to the extent that the sample is representative of the population. Finally, Kuwaiti firms have been excluded from the sample because of poor disclosure information.

Following the limitations highlighted above, there is a possibility of extending future examinations to other country settings that have comparable features and business environments to those of the present study, in order to determine its validity in different environments and time periods. Additionally, it is recommended that a longitudinal study be carried out, which examines the relationship of audit fees with audit quality. Furthermore, comparative studies among GCC countries may enrich the theory of audit demand. In addition, taking a sample from non-listed companies, family and non-family companies, small and medium-sized companies would offer new insights to the audit demand literature, theory, and the level of competition in the market.

Auditor independence in the GCC is deemed to be the most important implication that could be understood from of the results of this study. Significantly, the management of listed companies in the GCC would gain a deeper understanding of the issues related to audit fees that they will pay to their external auditors, and how this payment can determine the audit quality they demand. The management of the companies in the GCC should be aware that the audit quality has a direct relationship to the independence of the auditor, in that without independence the opinion of audit is meaningless. 


\section{Implications for Management and Stakeholders}

The findings of this study may serve to enhance the practices of corporate governance by management and shareholders, and may, as well, improve the demand for audit quality within the organization. The significance of having better practices of corporate governance ought to be recognized in making financial reporting to be more credible and quality oriented. It has not been considered a suitable practice for listed firms which have weak internal systems of corporate governance to appoint auditors with low-quality. In this environment, the shareholders who control the listed firms have the tendency of depriving the private benefits of exploiting small shareholders.

The results of this study would benefit banks in the way they assess the creditworthiness of incorporating companies in the GCC. The numbers appearing in audited financial statements mandate bond covenants. Moreover, credit decisions made by lenders are based on audited financial statements. Therefore, audit opinions are of the utmost importance for any lending institution. Investors and financial analysts depend on audited financial statements in making decisions related to bonds, bond rating, and all other decisions related to investments in GCC markets. Accordingly, increased understanding and prediction of companies' events are important to this user group.

All types of audit firms would benefit from an increased understanding of the audit environment within the GCC setting. This opportunity would help them assess the propriety of continuing their current strategies and policies to attract new clients and, therefore, enhance positive strategies and policies and correct negative ones. For instance, the audit firm may make decisions to adjust its audit proposal, change the audit team or staff, and/or make any other reasonable adjustment that would increase its chances of staying with the existing client, as well as attracting new ones.

\section{ACKNOWLEDGMENT}

This publication was supported by the Deanship of Scientific Research at Prince Sattam bin Abdulaziz University, Alkharj, Saudi Arabia 


\section{REFERENCES}

Abbott, L., \& Parker, S. (2000). Auditor selection and audit committee characteristics. Auditing, 19(2), 47-66.

Agrawal, A., \& Cooper, T. (2007, October). Corporate governance consequences of accounting scandals: Evidence from top management, CFO and auditor turnover. In 2nd Annual Conference on Empirical Legal Studies Paper.

Al-Hussaini, A \& Al-Sultan, W. (2008). Development of enforcement mechanisms following adoption of international accounting standards in the Gulf Co-Operation Council member states. International Journal Of Business Strategy, 8(3), 50-71

Aljifri, K., \& Khasharmeh, H. (2006). An investigation into the suitability of the international accounting standards to the United Arab Emirates environment. International Business Review, 15(5), 505-526.

Al-Shammari, B. (2008). Voluntary disclosure in Kuwait corporate annual reports. Review of Business Research, 8(1), 62-81.

Al-Shammari, B., Brown, P., \& Tarca, A. (2007). Development of enforcement mechanisms following adoption of International Accounting Standards in the Gulf Cooperation Council Member States. Working paper, University of Western Australia. Available at http://ssrn. com/author $=106179$.

Al-Shammari, B., Brown, P., \& Tarca, A. (2008). An investigation of compliance with international accounting standards by listed companies in the Gulf Co-Operation Council member states. The International Journal of Accounting, 43(4), 425-447.

Archambeault, D., \& DeZoort, F. (2001). Auditor opinion shopping and the audit committee: An analysis of suspicious auditor switches. International Journal of Auditing, 5(1), 33

Asiri, B. (2008). Testing weak-form efficiency in the Bahrain stock market. International Journal of Emerging Markets, 3(1), 38-53.

Beasley, M. (1996). An empirical analysis of the relation between the board of director composition and financial statement fraud. The Accounting Review, 71(4), 443-465.

Beasley, M. S., \& Petroni, K. R. (2001). Board independence and audit-firm type. Auditing: A Journal of Practice \& Theory, 20 (1), 97-114.

Beasley, M. S., Carcello, J. V., Hermanson, D. R., \& Lapides, P. D. (2000). Fraudulent financial reporting: Consideration of industry traits and corporate governance mechanisms. Accounting Horizons, 14(4), 441-454. 
Beattie, V., \& Fearnley, S. (1995). The importance of audit firm characteristics and the drivers of auditor change in UK listed companies. Accounting and Business Research, 25(100), 227-239.

Beattie, V., \& Fearnley, S. (1998a). Auditor changes and tendering: UK interview evidence Accounting, Auditing \& Accountability Journal, $11(1), 72-98$.

Beattie, V., \& Fearnley, S. (1998b). Audit market competition: auditor changes and the impact of tendering. The British Accounting Review, 30(3), 261-289.

Beattie, V., Brandt, R., \& Fearnley, S. (1999). Perceptions of auditor independence: UK evidence. Journal of International Accounting, Auditing and Taxation, 8(1), 67-107.

Beattie, V., Brandt, R., \& Fearnley, S. (2001). Behind closed doors: what company audit is really about. Palgrave Publisher, London.

Bedard, J., Ettredge, M., \& Johnstone, K. (2006). Using electronic audit work paper systems in audit practice: Task analysis, learning, and resistance. Advances in Accounting Behavioral Research 10(1), $29-53$.

Binder, G. (2009). Corporate governance in Arab countries: development of corporate governance in Arab and MENA countries. [Doctoral Dissertation]. University of Vienna, Vienna.

Blake, R. R., \& Mouton, J. S. (1960). The Managerial Grid: An Exploration of Key Managerial Orientations. Austin: Scientific Methods, Inc.

Blake, R. R., \& Mouton, J. S. (1964). The Managerial Grid. Houston: Gulf Pub. Co.

Blake, R. R., \& Mouton, J. S. (1965). A 9, 9 approach for increasing organizational productivity. In E. H Schein and W. G. Bennis (eds.) Personal and Organizational Change through Group Methods, New York: Wiley.

Bley, J., \& Chen, K. (2006). Gulf Cooperation Council (GCC) stock markets: The dawn of a new era. Global Finance Journal, 17(1), 75-91.

Blouin, J., Grein, B., \& Rountree, B. (2005). An analysis of forced auditor rotation: the case of former Arthur Andersen clients. Accounting Review, 82(3), 621-650.

Carcello, J. V., \& Nagy, A. L. (2002). Auditor industry specialization and fraudulent financial reporting. In Symposium on Auditing Problems.

Carcello, J. V., \& Neal, T. L. (2000). Audit committee composition and auditor reporting. The Accounting Review, 75(4), 453-467. 
Carcello, J., \& Nagy, A. (2004). Client size, auditor specialization and fraudulent financial reporting. Managerial Auditing Journal, 19(5), 651-668.

Carcello, J., \& Neal, T. (1998). Audit committee characteristics and auditor reporting. Working Paper, University of Tennessee.

Carcello, J., \& Neal, T. (2002). Audit committee composition and auditor dismissals. Working paper, University of Tennessee.

Carcello, J., \& Neal, T. (2003). Audit committee characteristics and auditor dismissals following" new" goingconcern reports. Accounting Review, 78(1), 95-117.

Carcello, J., Hermanson, D., Neal, T., \& Riley Jr, R. (2002). Board characteristics and audit fees. Contemporary Accounting Research, 19(3), 365-384.

Carey, P., \& Tanewski, G. (2000). Voluntary demand for internal and external auditing by family businesses. Auditing: A Journal of Practice \& Theory, 19(1), 37-51.

Carey, P., Craswell, A., \& Simnett, R. (2000). The association between the external audit fee and external auditors reliance on the work of internal audit. In AAANZ Conference, Hamilton Island, Australia, July.

Cassell, C. A., Giroux, G. A., Myers, L. A., \& Omer, T. C. (2012). The effect of corporate governance on auditorclient realignments. Auditing: A Journal of Practice \& Theory, 31(2), 167-188.

Chahine, S. (2007). Activity-based diversification, corporate governance, and the market valuation of commercial banks in the Gulf Commercial Council. Journal of Management and Governance, 11(4), 353382.

Chan, D. (1999). "Low Balling" and efficiency in a two period specialization model of auditing competition. Contemporary accounting research, 16(4), 609-642.

Chan, K. H., Lin, K. Z., \& Mo, P. L. L. (2006). A political-economic analysis of auditor reporting and auditor switches. Review of Accounting Studies, 11(1), 21-48.

Chan, K. H., Lin, K. Z., \& Zhang, F. (2007). On the association between changes in corporate ownership and changes in auditor quality in a transitional economy. Journal of International Accounting Research, 6(1), 19-36.

Chang, W. J., Chen, Y. S., \& Chan, M. P. (2009). Impact of audit fee deregulation on audit-market competition. Asia-Pacific Journal of Accounting \& Economics, 16(1), 69-94. 
Chang, X., Dasgupta, S., Hilary, G., \& Paris, H. (2009). The effect of auditor quality on financing decisions. The Accounting Review, 84, 1085-1117.

Che Ahmad, A., Houghton, K., \& Yusof, N. (2006). The Malaysian market for audit services: Ethnicity, multinational companies and auditor choice. Managerial Auditing Journal, 21 (7), 702-723.

Chen, C. J., Chen, S., \& Su, X. (2001). Profitability regulation, earnings management, and modified audit opinions: Evidence from China. Auditing: A Journal of Practice \& Theory, 20(2), 9-30.

Chen, K., \& Zhou, J. (2007). Audit committee, board characteristics, and auditor switch decisions by Andersen's clients. Contemporary Accounting Research, 24(4), 1085-1117.

Choi, J. H., \& Wong, T. J. (2007). Auditors' governance functions and legal environments: Aninternational investigation. Contemporary Accounting Research, 24(1), 13-46.

Claessens, S., Djankov, S., Fan, J. P., \& Lang, L. H. (2002). Disentangling the incentive and entrenchment effects of large shareholdings. The Journal of Finance, 57(6), 2741-2771.

Craswell, A. \& Francis, J. (1999). Pricing initial audit engagements: A test of competing theories. The Accounting Review, 74(2), 201-216.

Craswell, A. (1988). The association between qualified opinions and auditor switches. Accounting and Business Research, 19(73), 23

Craswell, A. (2003). Does the provision of non-audit services impair auditor independence? International Journal of Auditing, 3(1), 29-40.

Craswell, A. T., \& Taylor, S. L. (1991). The market structure of auditing in Australia: The role of industry specialization. Research in Accounting Regulation, 5(1), 55-77.

Craswell, A., Francis, J., \& Taylor, S. (1995). Auditor brand name reputations and industry specializations. Journal of Accounting and Economics, 20(3), 297-322.

DeAngelo, L. (1981a). Auditor Independence, 'Low Balling', and disclosure regulation. Journal of Accounting and Economics, 3(2), 113-127.

DeAngelo, L. (1981b). Auditor size and audit quality. Journal of Accounting and Economics, 3(3), 183-199.

DeAngelo, L. (1982). Mandated successful efforts and auditor choice. Journal of Accounting and Economics, 4(3), 171-203. 
DeBerg, C., Kaplan, S., \& Pany, K. (1991). An examination of some relationships between non-audit services and auditor change. Accounting Horizons, 5(1), 17-28.

DeFond, M. L. (1992). The association between changes in client firm agency costs and auditor switching. Auditing: A Journal of Practice \& Theory, 11(1), 16-31.

DeFond, M. L., \& Francis, J. R. (2005). Audit research after Sarbanes-Oxley. Auditing: A Journal of Practice \& Theory, 24(s-1), 5-30.

DeFond, M. L., Hann, R. N., \& Hu, X. (2005). Does the market value financial expertise on audit committees of boards of directors? Journal of Accounting Research, 43(2), 153-193.

DeFond, M. L., Wong, T. J., \& Li, S. (1999). The impact of improved auditor independence on audit market concentration in China. Journal of Accounting and Economics, 28(3), 269-305.

DeFond, M., \& Jiambalvo, J. (1991). Incidence and circumstances of accounting errors. Accounting Review, $66(3), 643-655$.

DeFond, M., \& Jiambalvo, J. (1993). Factors related to auditor-client disagreements over income-increasing accounting methods. Contemporary Accounting Research, 9(2), 415-431.

Desender, K. A., Aguilera, R. V., Crespi-Cladera, R., \& Garcia-Cestona, M. A. (2009). Board characteristics and audit fees: Why ownership structure matters (No. 09-0107).

Dopuch, N., \& Simunic, D. (1982). Competition in auditing: An assessment. In Fourth Symposium on auditing research (pp. 401-450). University of Illinois.

Eichenseher, J. (1985). The effect of foreign operations on domestic auditor selection. Journal of Accounting, Auditing, and Finance, 8(3), 195-209.

Eichenseher, J. (1995). Additional factors in audit pricing-new evidence from Malaysia. Accounting Business Review, 2(1), 1-26.

Eichenseher, J. W, \& Shields, D. (1989). Corporate capital structure and auditor fit. Advances in Accounting: A Research Annual, 1, 39-56.

Eichenseher, J., \& Danos, P. (1981). The analysis of industry-specific auditor concentration: Towards an explanatory model. Accounting Review, 56(3), 479-492.

Eichenseher, J., \& Shields, D. (1983). The correlates of CPA-firm change for publicly held corporations. Auditing: A Journal of Practice \& Theory, 2(2), 23-37. 
Eichenseher, J., Hagigi, M., \& Shields, D. (1989). Market reaction to auditor changes by OTC companies. Auditing: A Journal of Practice \& Theory, 9(1), 29-40.

Ettredge, M., \& Greenberg, R. (1990). Determinants of fee cutting on initial audit engagements. Journal of Accounting Research, 28(1), 198-210.

Fargher, N., Taylor, M., \& Simon, D. (2001). The demand for auditor reputation across international markets for audit services. The International Journal of Accounting, 36(4), 407-421.

Francis, J. R. (1984). The effect of audit firm size on audit prices: A study of the Australian market. Journal of Accounting and Economics, 6(2), 133-151.

Francis, J., \& Wilson, E. (1988). Auditor changes: A joint test of theories relating to agency costs and auditor differentiation. The Accounting Review, 63(4), 663-682.

Francis, J., I. Khurana, \& R. Pereira. (2003). The role of accounting and auditing in corporate governance, and the development of financial markets around the world. Asian-Pacific Journal of Accounting and Economics, 10 (1), 1-30.

Guedhami, 0., Pittman, J. A., \& Saffar, W. (2009). Auditor choice in privatized firms: Empirical evidence on the role of state and foreign owners. Journal of Accounting and Economics, 48(2), 151-171.

Gulf Base. (2009). GCC economic overview. Retrieved September, 2009, from http://www.gulfbase.com/Site/ Interface/TheGCC/gccoverview.html.

Haniffa, R.M., \& Cooke, T.E. (2002). Culture, corporate governance and disclosure in Malaysian corporations. Abacus, 38(3), 317-349.

Harabi, N. (2007). State of Corporate Governance in Arab Countries: An Overview. MPRA unpublished paper, MPRA: Munich Personal RePEc Archive. Retrieved August 12, 2009, from http://mpra.ub.uni-muenchen. de/4566/.

Haskins, M., \& Williams, D. (1990). A contingent model of intra-big eight auditor changes. Auditing: A Journal of Practice \& Theory, 9(3), 55-74.

Hogan, C. E. (1997). Costs and benefits of audit quality in the IPO market: A self-selection analysis. The Accounting Review, 72(1), 67-86.

Hope, O. K., Kang, T., Thomas, W., \& Yoo, Y. K. (2008). Culture and auditor choice: A test of the secrecy hypothesis. Journal of Accounting and Public Policy, 27(5), 357-373. 
Hudaib, M., \& Cooke, T. (2005). The impact of managing director changes and financial distress on audit qualification and auditor switching. Journal of Business Finance \& Accounting, 32(9-10), 1703-1739.

Hussain, M., Islam, M. M., Gunasekaran, A., \& Maskooki, K. (2002). Accounting standards and practices of financial institutions in GCC countries. Managerial Auditing Journal, 17(7), 350-362.

Ismail, S., Nassir, A., Aliahmed, H., \& Hamid, M. (2006). Wealth effect of auditor switch during crisis and noncrisis period: The Malaysian experience. Editor-In-Chief, 3(2), 124-134.

Jackson, A. B., Moldrich, M., \& Roebuck, P. (2008). Mandatory audit firm rotation and audit quality. Managerial Auditing Journal, 23(5), 420-437.

Jensen, M. (2010). The modern industrial revolution, exit, and the failure of internal control systems. Journal of Applied Corporate Finance, 22(1), 43-58.

Jensen, M., \& Meckling, W. (1976). Theory of the firm: Managerial behavior, agency costs, and capital structure. Journal of financial economics, 3(4), 305-360.

Johnson \& Lys (1990). The market for audit services: evidence from voluntary auditor changes. Journal of Accounting and Economics, 12 (1-3), 281-308.

Khalil, S., Cohen, J., \& Trompeter, G. (2010). Auditor resignation, audit firm client valuation and firm ownership structure. Working paper: Boston, MA: Boston College.

Khanna, T., \& Palepu, K. (2000). The future of business groups in emerging markets: Long-run evidence from Chile. The Academy of Management Journal, 43(3), 268-285.

Knechel, W. R. (2001). Auditing: Assurance and risk(2nd ed.). South Western College Publishing.

Knechel, W. R., \& Willekens, M. (2006). The role of risk management and governance in determining audit demand. Journal of Business, Finance \& Accounting, 33(9-10), 1344-1367.

Knechel, W. R., Naiker, V., \& Pacheco, G. (2007). Does auditor industry specialization matter? Evidence from market reaction to auditor switches. Auditing: A Journal of Practice \& Theory, 26(1), 19-45.

Knechel, W. R., Niemi, L., \& Sundgren, S. (2008). Determinants of auditor choice: Evidence from a small client market. International Journal of Auditing, 12(1), 65-88.

Knechel, W., \& Vanstraelen, A. (2007). The relationship between auditor tenure and audit quality implied by going concern opinions. Auditing: A Journal of Practice \& Theory, 26(1), 113-131. 
Koh, H., \& Woo, E. (2001). The auditor-manager expectation gap in auditing. Managerial Auditing Journal, 16(3), 176-188.

Koh, P. S. (2003). On the association between institutional ownership and aggressive corporate earnings management in Australia. The British Accounting Review, 35(2), 105-128.

Lee, H., Mande, V., \& Ortman, R. (2004). The effect of audit committee and board of director independence on auditor resignation. Auditing: A Journal of Practice \& Theory, 23(2), 131-146.

Lennox, C. (2000). Do companies successfully engage in opinion-shopping? Evidence from the UK. Journal of Accounting and Economics, 29(3), 321-337.

Lim, C. Y., \& Tan, H. T. (2010). Does auditor tenure improve audit quality? Moderating effects of industry specialization and fee dependence. Contemporary Accounting Research, 27(3), 923-957.

Lin, Z., Liu, M., \& Wang, Z. (2009). Market implications of the audit quality and auditor switches: Evidence from China. Journal of International Financial Management \& Accounting, 20(1), 35-78.

Lindah. F.W . (1994). How much do we know about auditor changes? The effect of observed and unobserved heterogeneity. Working paper, George Washington University.

Low, C. K. (2002). Corporate governance: an Asia-Pacific critique. Sweet \& Maxwell Asia, Hong Kong.

Menon, K. \& D. Williams (1991). Auditor credibility and initial public offerings. The Accounting Review 66(2), 313-332.

Menon, K., \& Schwartz, K. (1985). Auditor switches by failing firms. The Accounting Review 60(2), 248-261.

Menon, K., \& Williams, D. (2008). Management turnover following auditor resignations. Contemporary accounting research, 25(2), 567-604.

Meyer, J. W., \& Rowan, B. (1977). Institutionalized organizations: Formal structure as myth and ceremony. The American Journal of Sociology, 83(2), 340-363.

Myers, S. C., \& Majluf, N. S. (1984). Corporate financing and investment decisions when firms have information that investors do not have. Journal of Financial Economics, 13(2), 187-221.

Nazri, S. N. F. S. M., Smith, M., \& Ismail, Z. (2012a). Factors influencing auditor change: Evidence from Malaysia. Asian Review of Accounting, 20(3), 222-240.

Nazri, S. N. F. S. M., Smith, M., \& Ismail, Z. (2012b). The impact of ethnicity on auditor choice: Malaysian evidence. Asian Review of Accounting, 20(3), 198-221. 
Neal, TL. (1998). audit committee effectiveness: an examination of audit committee composition and auditor switching [Doctoral dissertation]. The University of Tennessee, Knoxville.

Omran, M. M., Bolbol, A., \& Fatheldin, A. (2008). Corporate governance and firm performance in Arab equity markets: Does ownership concentration matter? International Review of Law and Economics, 28(1). 32-45.

O'Sullivan, N., \& Diacon, S. R. (2006). The impact of ownership, governance and non $\square$ audit services on audit fees: Evidence from the insurance industry. International Journal of Auditing, 6(1), 93-107.

Palmrose, Z. (1984a). Size related surrogates for quality and the pricing of audit services. Unpublished Working Paper, University of California-Berkeley.

Palmrose, Z. V. (1984b). The demand for quality-differentiated audit services in an agency-cost setting: An empirical investigation. In Proceedings of the Sixth Symposium on Auditing Research, edited by AR AbdelKahlik and I. Solomon, University of Illinois Press, Champaign (pp. 229-252).

Riaño, S. C. G. (2009). Gobierno corporativo en Colombia. Tendencias actuales. AD-minister, (15), 137-153.[ Riaño, S. G. (2009). Corporate Governance in Colombia. Current trends. [ AD-Minister, 15, 137-153, Universidad Eafit- Medellin, Colombia.

Roberts, R., Glezen, G., \& Jones, T. (1990). Determinants of auditor change in the public sector. Journal of Accounting Research, 28(1), 220-228.

Salehi, M., Komeili, F., \& Daemi Gah, A. (2019). The impact of financial crisis on audit quality and audit fee stickiness: evidence from Iran. Journal of Financial Reporting and Accounting, 17(2), 201-221.

Salehi, M., Jafarzadeh, A., \& Nourbakhshhosseiny, Z. (2017). The effect of audit fees pressure on audit quality during the sanctions in Iran. International Journal of Law and Management, 59 (1), 66-81.

Schwartz, K., \& Menon, K. (1985). Auditor switches by failing firms. Accounting Review, 60(2), 248-261.

Schwartz, K., \& Soo, B. (1996). The association between auditor changes and reporting lags. Contemporary Accounting Research, 13(1), 353-370.

Simon, D., \& Francis, J. (1988). The effects of auditor change on audit fees: Tests of price cutting and price recovery. The Accounting Review, 63(2), 255.

Simunic, D. (1980). The pricing of audit services: theory and evidence. Journal of Accounting Research, 18(1), 161-190. 
Simunic, D. A, \& Stein, M. T. (1987). Product differentiation in auditing, auditor choice in the market for unseasoned new issues. Vancouver, B.C.: Canadian Certified General Accountants" Research Foundation, No. 13.

Simunic, D., \& Stein, M. (1990). Audit risk in a client portfolio context. Contemporary Accounting Research, 6(2), 329-343.

Tay, J. S. W., \& Parker, R. H. (1990). Measuring international harmonization and standardization. Abacus, 26(1), 71-88.

Wang, M. (2009). The effects of firm market value on audit partner tenure and firm profitability. Accounting \& Taxation, 1(1), 115-120

Wang, Q., Wong, T. J., \& Xia, L. (2008). State ownership, the institutional environment, and auditor choice: Evidence from China. Journal of Accounting and Economics, 46(1), 112-134.

Williams, D. (2006). The potential determinants of auditor change. Journal of Business Finance \& Accounting, 15(2), 243-261.

Williams, D. D. (1988). The potential determinants of auditor change. Journal of Business, Finance \& Accounting, 15(2), 243-261.

Williams, K., Morris, M., Leung, K., Bhatnagar, D., Hu, J., Kondo, M., et al. (1998). Culture, conflict management style, and underlying values: accounting for cross-national differences in style of handling conflict among US, Chinese, Indian, and Filipino managers. Journal of International Business Studies, 29(4), 729-747.

Woo, E., \& Koh, H. (2001). Factors associated with auditor changes: a Singapore study. Accounting and Business Research, 31(2), 133-144.

World Bank. (2012). Indicators. Available at http://data.worldbank.org/indicator/IC.PI.INV 